\title{
Transport and Deposition of Activation Products in a Helium Cooled Fusion Power Plant
}

W. E. Bickford

September 1980

Prepared for

EG\&G Idaho, Inc. and

the Department of Energy

under Contract DE-AP07-791-D0020

Pacific Northwest Laboratory

Operated for the U.S. Department of Energy

by Battelle Memorial Institute 


\title{
NOTICE
}

This report was prepared as an account of work sponsored by the United States Government. Neither the United States nor the Department of Energy, nor any of their employees, nor any of their contractors, subcontractors, or their employees, makes any warranty, express or implied, or assumes any legal liability or responsibility for the accuracy. completeness or usefulness of any information, apparatus, product or process disclosed, or represents that its use would not infringe privately owned rights.

The views, opinions and conclusions contained in this report are those of the contractor and do not necessarily represent those of the United States Government or the United States Department of Energy.

\author{
PACIFIC NORTHWEST LABORATORY \\ operated by \\ BATTELLE \\ for the \\ UNITED STATES DEPARTMENT OF ENERGY \\ Under Contract DE-AC06-76RLO 1830
}
Printed in the United States of America Available from
National Technical Information Service United States Department of Commerce 5285 Port Royal Road
Springfield. Virginia 22151

Price: Printed Copy $\$$ $\because$ Microfiche $\$ 3.00$

NTIS

*Pages Selling Price

\begin{tabular}{ll}
$001-025$ & $\$ 4.00$ \\
$026-050$ & $\$ 4.50$ \\
$051-075$ & $\$ 5.25$ \\
$076-100$ & $\$ 6.00$ \\
$101-125$ & $\$ 6.50$ \\
$126-150$ & $\$ 7.25$ \\
$151-175$ & $\$ 8.00$ \\
$176-200$ & 59.00 \\
$201-225$ & $\$ 9.25$ \\
$226-250$ & $\$ 9.50$ \\
$251-275$ & $\$ 10.75$ \\
$276-300$ & $\$ 11.00$ \\
\hline
\end{tabular}




\section{0}

TRANSPORT AND DEPOSITION OF

ACTIVATION PRODUCTS IN A HELIUM

COOLED FUSION POWER PLANT

W. E. Bickford

September 1980

Prepared for

EG\&G Idaho, Inc. and

the Department of Energy

under Contract DE-AP07-791-D0020

Pacific Northwest Laboratory

Richland, Washington 99352 


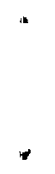

$+$ 


\section{SUMMARY}

The transport and deposition of neutron activation products in a helium cooled tokamak fusion power plant are investigated. Stainless steel is used as coolant channel material for a helium/steam system.

The important gamma emitting nuclides ${ }^{56} \mathrm{Mn},{ }^{54} \mathrm{Mn},{ }^{57} \mathrm{Co},{ }^{58} \mathrm{Co},{ }^{60} \mathrm{Co},{ }^{51} \mathrm{Cr}$, and ${ }^{99} \mathrm{Mo}$ are considered. The dominant release mechanism identified is direct daughter recoil emission from $(n, x)$ type reactions. Corrosion and evaporation are discussed. The radionuclide inventory released by these mechanisms is predicted to exceed $1 \times 10^{4} \mathrm{Ci}$ for a reference reactor design after only several days of operation, and approach $3.5 \times 10^{4} \mathrm{Ci}$ in equilibrium. A mass transport mode 1 is then used to predict the deposition pattern of this inventory in the reactor cooling system.

The results indicate that the blanket regions of the reactor can be designed to promote deposition within the reactor itself, reducing radiation hazards in the outer portions of the cooling loop. The design as given predicts $17 \%$ deposition in the blanket, $8 \%$ in the hot pipe runs, and $75 \%$ in the steam generators. Predicted contact dose rates range from $10 \mathrm{R} / \mathrm{hr}$ on pipes directly out of the reactor to $100 \mathrm{mR} / \mathrm{hr}$ on the steam generators. Internal shielding and the assumed shell thickness reduce doses on the steam generator substantially.

The predicted inventory of ${ }^{56} \mathrm{Mn}$ entrained in the coolant $(0.8 \mathrm{Ci})$ may provide hazards in loss of coolant type accidents. This is considered an onsite occupational problem rather than an environmental hazard, as the released activation products are expected to plate out readily on surfaces in the containment building. However, deposition rates and the impact on containment filtering and atmosphere spray systems should still be assessed. 


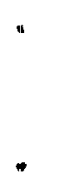




\section{CONTENTS}

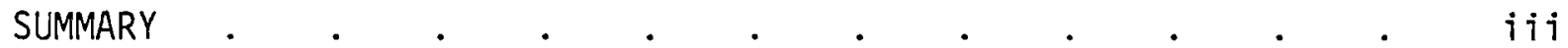

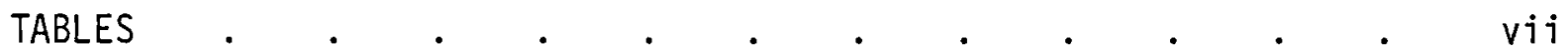

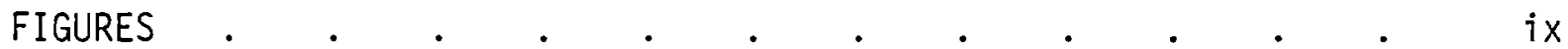

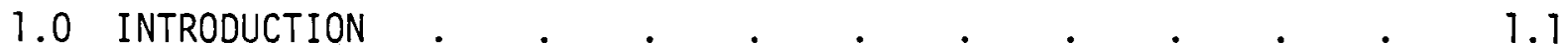

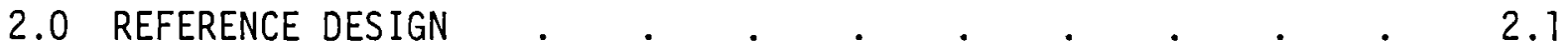

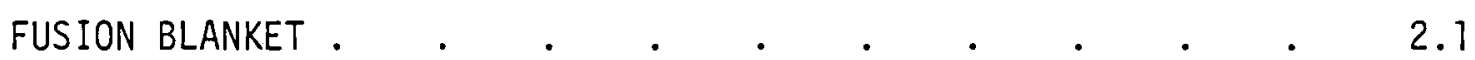

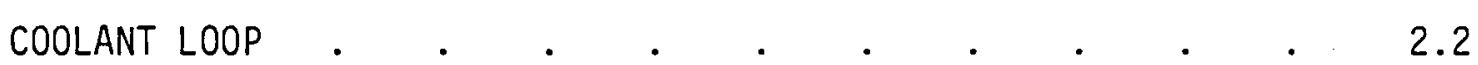

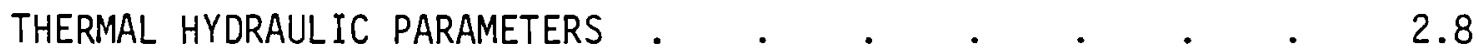

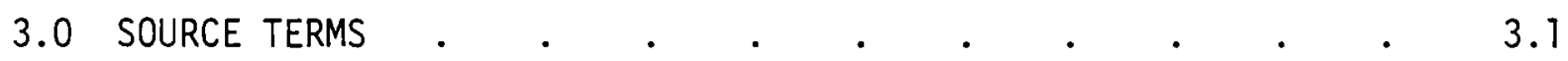

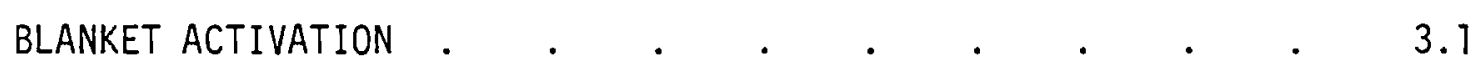

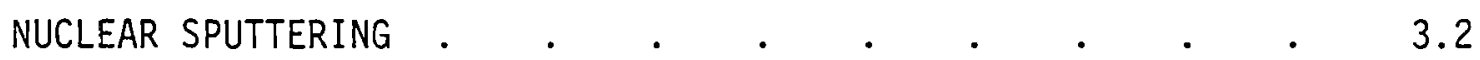

CORROSION

EVAPORATION

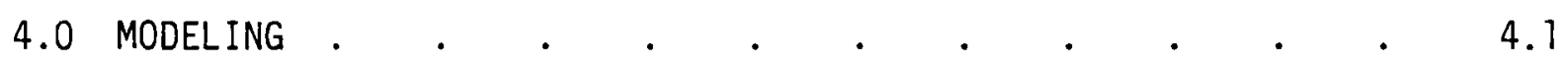

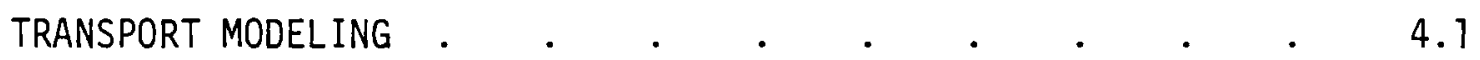

COUPLED COOLANT-SURFACE CONCENTRATION EQUATION $\quad . \quad$ e $\quad . \quad 4.4$

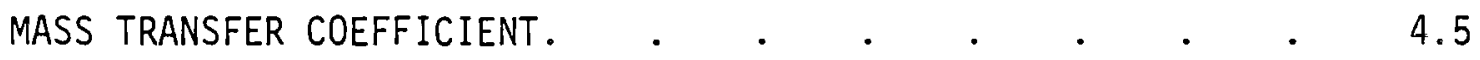

MODEL VALIDITY

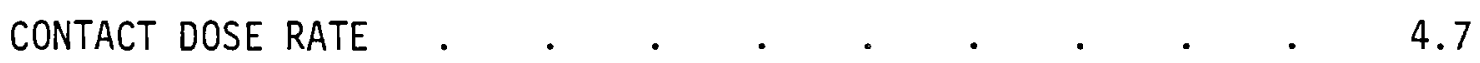

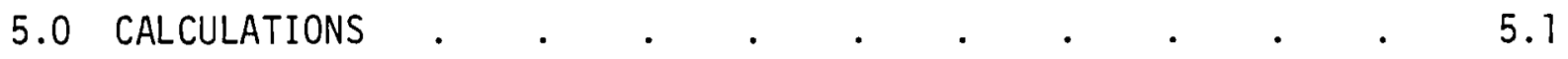

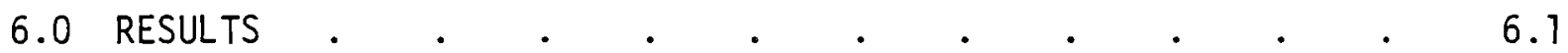

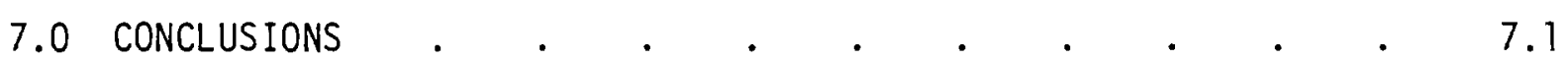

REFERENCES. . . . . . . . . . . . . .

DISTRIBUTION . $\quad . \quad$. . . . . . . . . Distr-1 
"

. 


\section{$\underline{\text { TABLES }}$}

1 Reference Tokamak Reactor Parameters . . . . . $\quad$. 2.2

2 Helium Flow by Component. . . . . . . . . 2.10

3 Blanket Coolant Loop Thermal Hydraulics . . . . . 2.11

4 Coolant Channel Surface Area in 648 Modules . . . . 2.13

5 Blanket Module Thermal Hydraulics . $5 . \quad$. $\quad . \quad$. 2.14

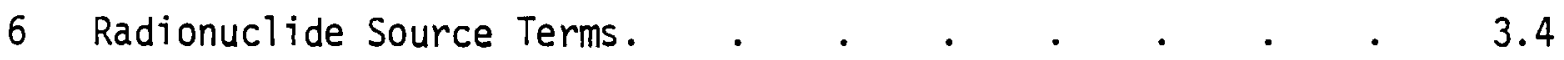

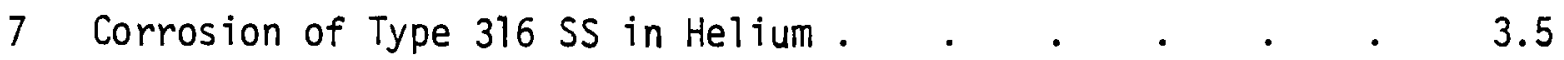

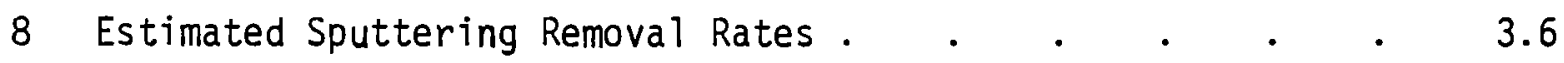

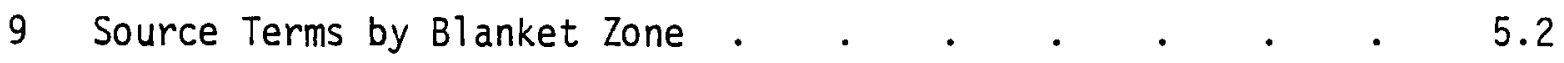

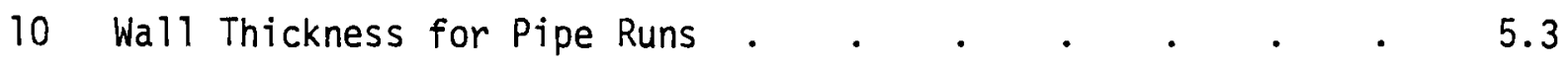

11 Average Inventories in the Blanket Module . . . . 6.2

12 Average Inventories in the Coolant Loop . . . . . . . 6.3

13 Surface Buildup in the Toroidal Manifold. . . . . . 6.4

14 Activity in the Coolant Loop . . . . . . . . . . . 6.5

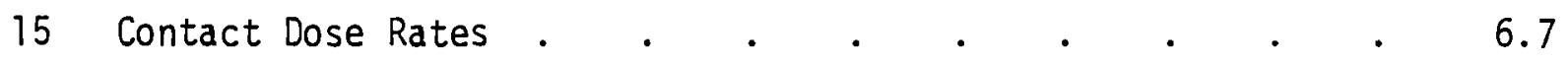

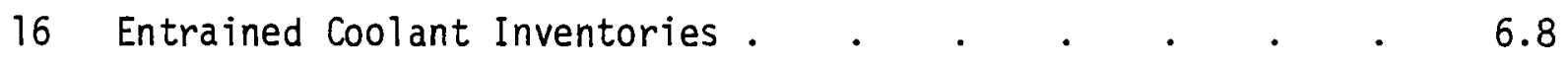




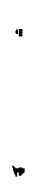




\section{FIGURES}

1 Cross-Section of a Blanket Module . . . . . . . 2.1

2 Blanket Ring Segment. . . . . . . . . . . 2.3

3 Blanket Module Coolant Branch Network . . . . . $\quad .4$

4 Reactor Coolant Branch Network. . . . . . . . 2.6

5 Reactor Coolant Loop. . . . . . . . . . 2.7

6 Helium Piping Geometry in the Steam Generator Cell. . . 2.8

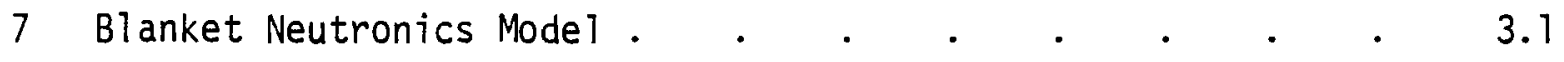

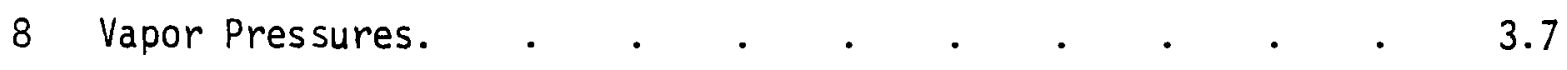


'

-

,

. 


\subsection{INTRODUCTION}

Nuclear fusion has the potential for providing an essentially limitless energy supply in the coming decades. The U.S. magnetic fusion energy program is currently geared towards demonstrating the feasibility of this energy source in the 1980s. The most promising reaction is based on the fusion of the hydrogen isotopes of deuterium and tritium. This reaction produces a high energy neutron which, when captured in surrounding materials, can produce radioactive activation products.

The presence of activation products can potentially raise the demand for a whole range of safety and environmental control measures. However, the fusion concept has a major advantage over fission in that no radioactive materials are produced directly by the D-T fusion process. With the proper choice of materials and design, the fusion plant designer can potentially reduce or even eliminate the presence of some radioactive materials and their associated impact on plant safety and environmental considerations.

As the lead laboratory for the U.S. Magnetic Fusion Safety Program, much of the work sponsored by EG\&G Idaho, Inc. is directed towards the above goal. It is recognized that all activation products cannot be entirely eliminated, however, efforts can be made to control the form and location or the unwanted transport of materials throughout reactor systems.

Experience in the fission reactor industry has indicated that the transport of activation products through the coolant system will result in a major source of plant occupational radiation exposure. Deposition of activated erosion or corrosion products in the coolant loop often occurs in pumps, valves and heat exchangers which require periodic maintenance. This has been true in light water reactors $(1)$ as well as gas cooled ${ }^{(2)}$ and liquid metal cooled (3) reactors. Indications are that this problem should be examined in magnetic fusion power plants.

The source terms required to assess the problem of activation product transport in a fusion reactor cooling system will depend greatly on the type of coolant and materials chosen, as well as operating conditions. Sources 
can include the coolant itself or coolant impurities and corrosion or sputtering products released into the coolant stream. Operation at high temperatures can also result in evaporation of coolant channel material.

The initial examination of this problem will focus on a helium cooled design using stainless steel structures. Helium has been chosen for blanket cooling in a number of recent tokamak designs for its thermal efficiency and chemical inertness. Stainless steel is also a likely candidate for structural and coolant channel materials in the first generation of fusion plants.

In the following chapters, transport models will be developed, along with a reference design description complete with cooling system and coolant flow parameters. Activation product source terms will then be identified, followed by transport and deposition calculations around the coolant loop. Inventories and contact surface dose rates will be presented. 


\subsection{REFERENCE DESIGN}

The fusion blanket design will be presented here along with the associated helium coolant loop to circulators and steam generators. Helium flow rates will be established.

\section{FUSION BLANKET}

The reference design chosen for these calculations is a PNL modification (4) of the demonstration tokamak power plant developed at Oak Ridge by Steiner, et a1. (5) which is referred to here as the ORNL-DEMO. The major difference is an attempt to use helium as the first wall and blanket coolant where the ORNL-DEMO used a commercial molten salt mixture. All other aspects are those for the ORNL-DEMO contour blanket option, a cross-section of which is shown in Figure 1.

The major machine parameters for this design are given below in Table 1 .

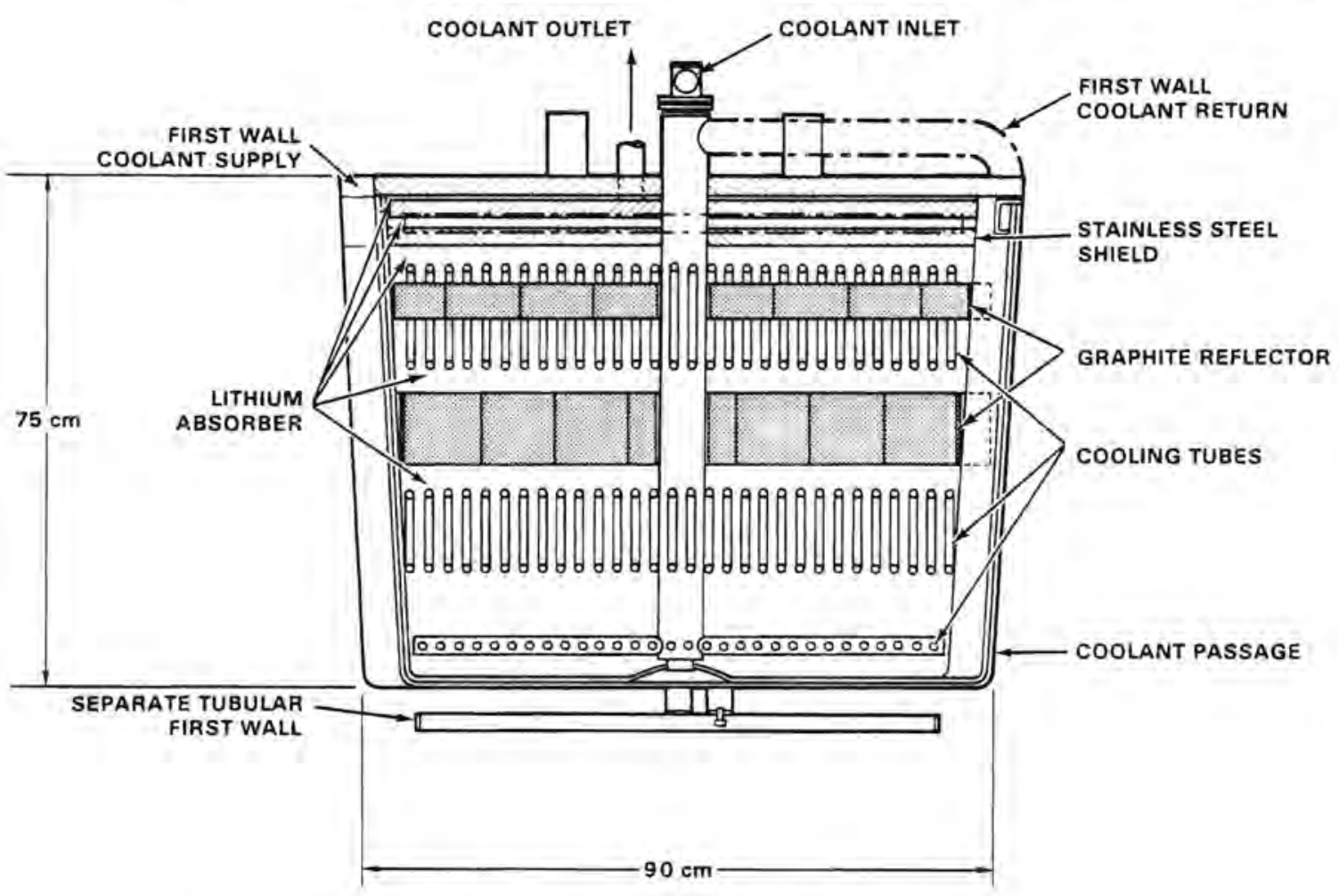

FIGURE 1. Cross-Section of a BTanket ModuTe ${ }^{(5)}$ 


\begin{tabular}{cc} 
TABLE 1. Reference Tokamak Reactor & Parameters \\
\hline Major Radius, m & 6.0 \\
Wall Area, m & 474.0 \\
Toroidal Field Coils & 18 \\
Modules in Blanket & 648 \\
Neutron Wall Loading, MW/m & 3.0 \\
Power Output, MW & th \\
Neutron & 2,260 \\
Alpha & 1,422 \\
Exothermic Blanket & 353 \\
\end{tabular}

There are four distinct regions in the blanket module containing helium coolant channels. One is the tubular first wall, and the other three are the regions containing stagnant lithium separated by graphite reflectors.

The modules are assembled into blanket ring segments, as shown in Figure 2. There are 12 modules per segment, with the helium manifolds contained in the ring support structure. The entire blanket consists of 54 segments, giving a total of 648 modules. Main toroidal helium manifolds above and below the torus are then required for delivery and removal of helium from the blanket as shown in Figure 2.

\section{COOLANT LOOP}

To model activation product transport in the reactor design just given, the branch network in the blanket modules must be developed, as well as all delivery and return manifolds and piping to steam generators and circulators. To accomplish this, the branch network will be stylized somewhat using the modeling techniques developed by General Atomic in the PAD ${ }^{(6)}$ and PADLOC ${ }^{(7)}$ computer codes to model fission product transport in gas cooled reactors.

The necessary branch network in the blanket modules would be as follows:

- inlet from ring segment manifold

- delivery channels to first wall and blanket zones 


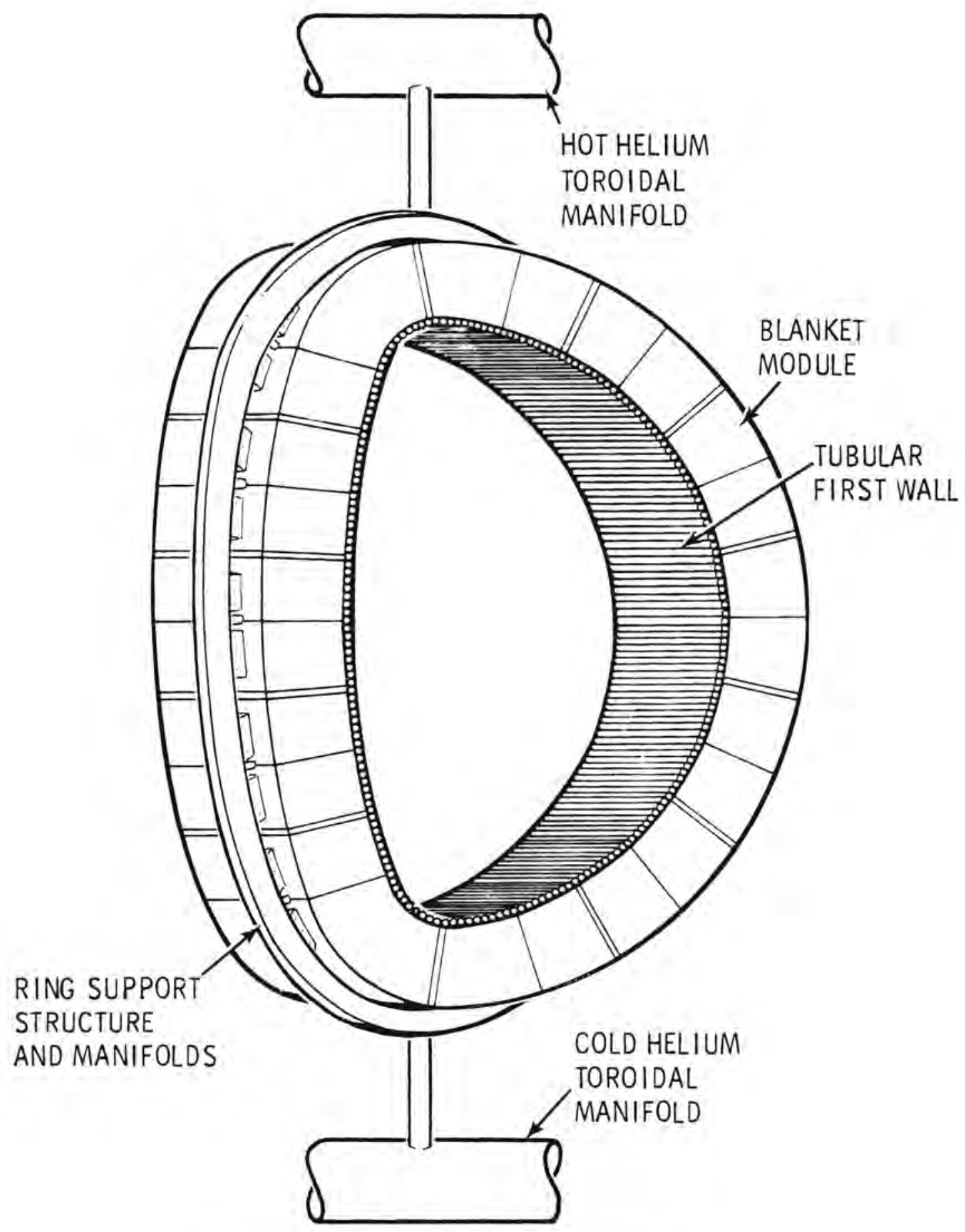

FIGURE 2. Blanket Ring Segment 
- the actual coolant channels in all zones

- collection channels from all zones

- outlet to ring segment manifold.

The branch network described is shown in Figure 3 . The coolant channels in the first wall (Zone 3) and blanket (Zones 5, 7, and 9) will be modeled as a group of tubes with helium flow from a common delivery and collection plenum for simplicity. The zone designations for the first wall and blanket are from the neutronics model used to identify activation product inventories in the blanket material as will be discussed in Chapter 3. The branch network shown will then be used in Chapter 4 to model the release of activation products from the blanket and their subsequent transport through the cooling system.

The remaining portion of the helium coolant loop must do the following:

- collect coolant from modules in the ring header

- deliver coolant to the toroidal supply manifold

- run from the hot manifold to the steam generator

- run through the helium circulator

- return to the cold toroidal manifold for distribution to the blanket.

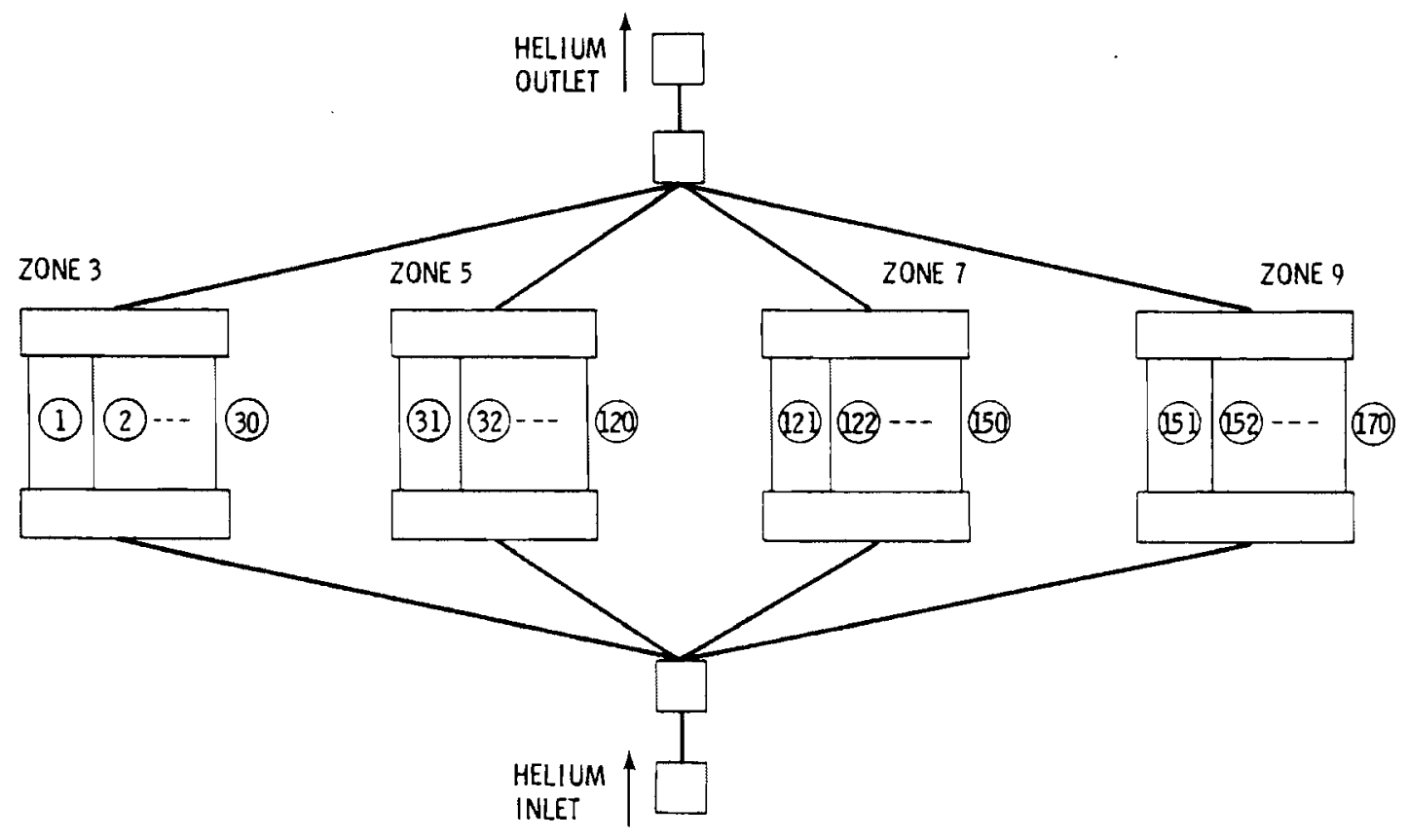

FIGURE 3. Blanket Module Coolant Branch Network 
Several options are available for the location of steam generators and the above associated piping. The easiest system to model would locate the steam generators at uniform distances circumferentially around the torus as shown schematically in Figure 4. This divides the blanket up into a number of essentially independent loops, all of which share the same characteristics for activation product transport modeling. Note in Figure 4 that the toroidal manifolds above and below the reactor are divided into discrete branches between the junction to the blanket ring segments. This makes it possible to account for the flow changes that will occur along the manifold. The same technique is used for the ring segment manifold, shown in Figure 4 , each of which serves 12 blanket modules.

In actual fact, it may be more sound to locate the steam generators in a common location adjacent to the containment building, as in the helium cooled UWMAK-II design. ${ }^{(8)}$ This type of pipe run is shown pictorially in Figure 5. Here, one common manifold from the toroidal manifold above the reactor would serve the entire bank of steam generators. However, for this first examination, the more simplistic branch network shown in Figure 4 shall be used.

Within the steam generator cells, dose calculations at various locations are possible given the exact configurations of piping and components. This was done for the liquid metal cooled Fast Flux Test Facility (FFTF) at Hanford. $(9,10)$ However, fusion reactor designs have not been developed to this degree of sophistication. The pipe geometry within the cell would only be speculative at this point, and dose calculations based on the contribution from a number of components would be of little value. However, the total length and diameter of the pipe runs would be important for transport and deposition calculations.

The length of pipe runs between components can be significant to allow for thermal expansion and contraction. This was the case in the Peach Bottom HTGR, where the convoluted pipe run between the steam generator and helium circulator appears to be approximately 45 meters in length. (11) Figure 6, a close-up view of one of the steam generator cells shown in Figure 5 , gives an example of the type of geometry and pipe runs expected. Steam 1 ines and other components are not shown. Again, however, these details will be omitted in the preliminary examination of the problem in fusion reactors. 


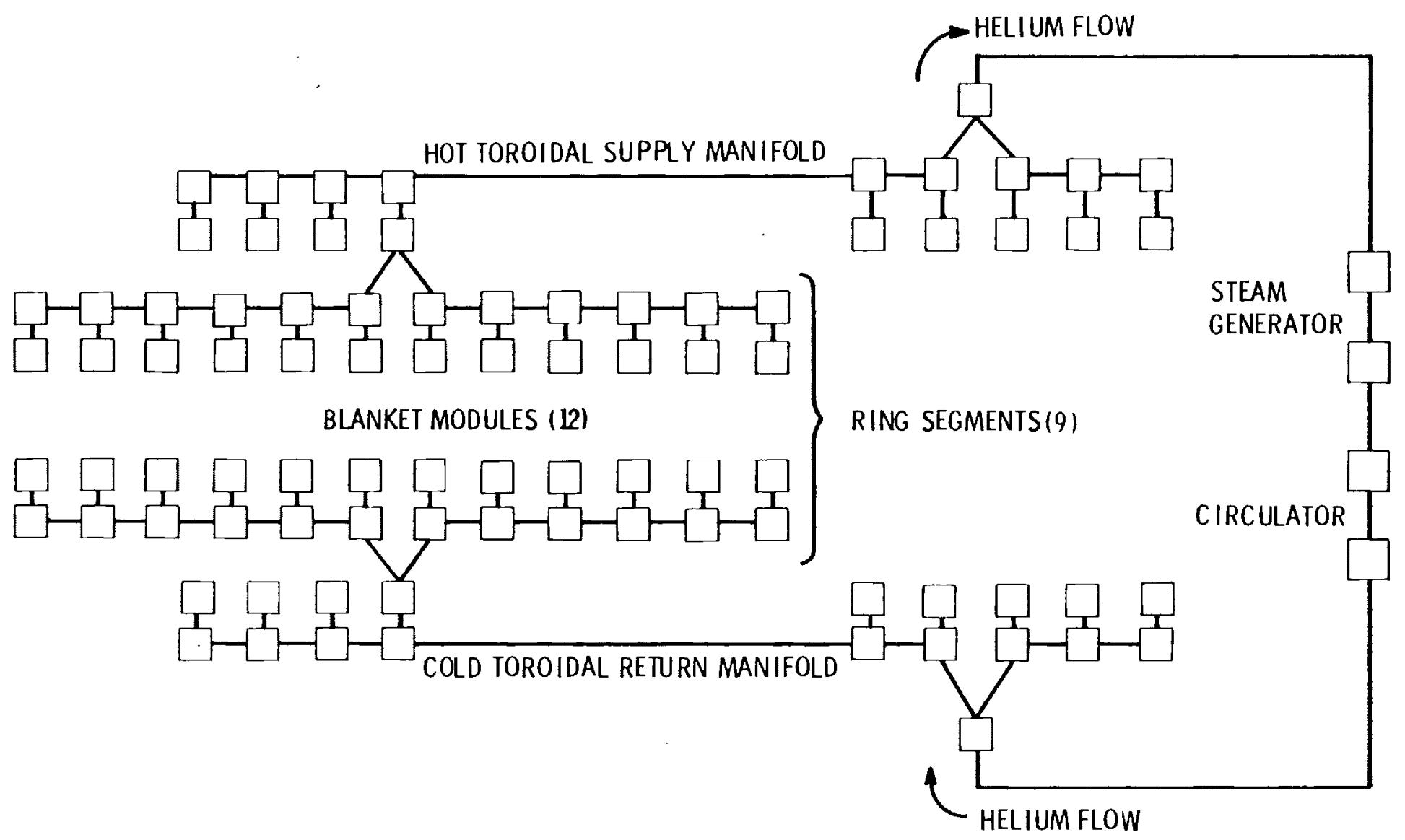

FIGURE 4. Reactor Coolant Branch Network 


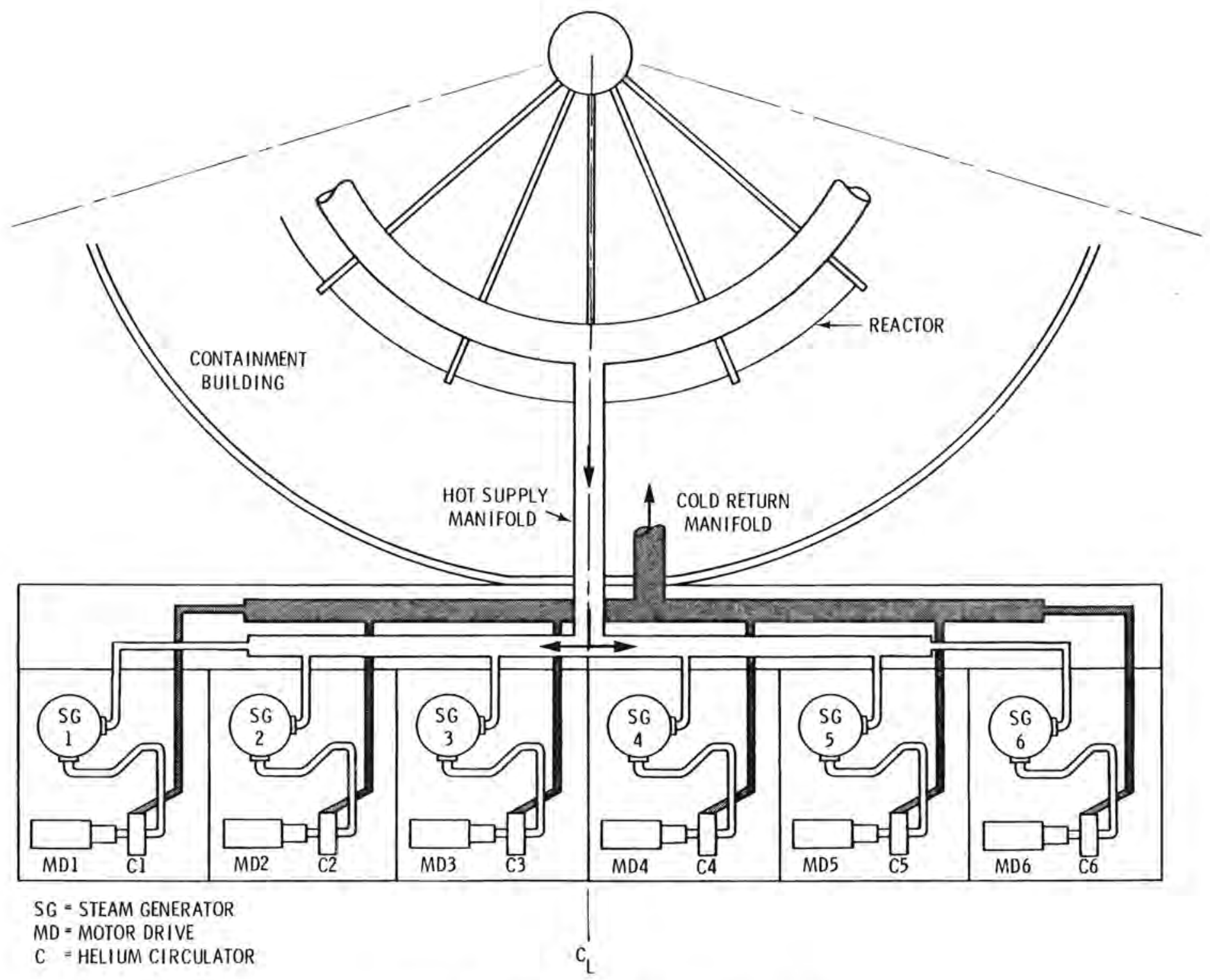

FIGURE 5. Reactor Coolant Loop 


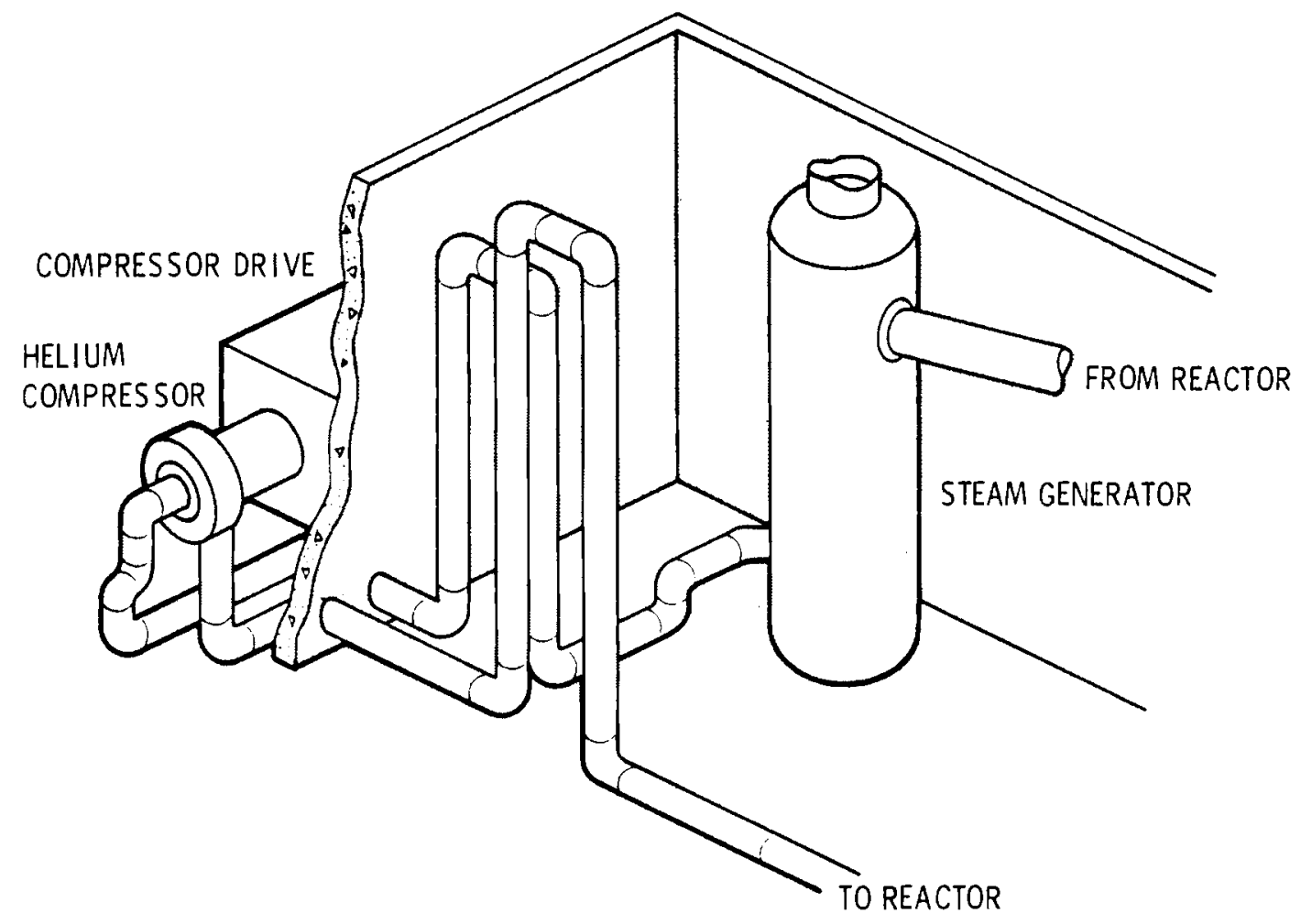

FIGURE 6. Helium Piping Geometry in the Steam Generator Cell

\section{THERMAL HYDRAULIC PARAMETERS}

As mentioned previously, the original contour blanket option for the ORNL DEMO reactor is cooled by eutectic salts. ${ }^{(5)}$ The use of helium coolant was extensively evaluated for the cassette blanket option, ${ }^{(12)}$ however, no selfconsistent design has been developed for the PNL helium cooled modification of the contour blanket. The purpose here is to model activation product transport, and thus, a complete thermal hydraulic analysis of the reference design is beyond the scope of this investigation. However, the results of the transport and deposition mode 1 will depend heavily on the values chosen for pipe diameters and lengths as we11 as helium pressures, temperatures, and mass flow rates. As such, an attempt must be made to arrive at reasonably self-consistent first wa11 heat loads and cooling system performance. This will be done here. 
In the UWMAK-II design, the maximum operating temperature of helium cooled stainless steel was 1 imited to approximately $600^{\circ} \mathrm{C}$ by creep rupture 1 ife and radiation damage considerations. This limit was considered most important for stress bearing structures, but was relaxed for components in the interior of the blanket modules. The maximum first wall temperature was set at $550^{\circ} \mathrm{C}$ with a maximum stress of 10,000 psi. Structura 1 temperatures in the blanket reached $686^{\circ} \mathrm{C}$. (13) Helium pressure was $\sim 50$ atmospheres, with inlet and outlet temperatures of $450^{\circ} \mathrm{C}$ and $650^{\circ} \mathrm{C}$, respectively, for a He/ Na/steam heat transfer system. The GA-DEMO design used inlet and outlet temperatures of $350^{\circ} \mathrm{C}$ and $650^{\circ} \mathrm{C}$, respectively, for a $\mathrm{He} / \mathrm{steam}$ system of a helium pressure of $50 \mathrm{~atm}$. (14)

However, in the more recent examination of temperature restrictions for helium cooled stainless steel in the ORNL cassette blanket, a $500^{\circ} \mathrm{C}$ maximum blanket temperature limit was suggested. ${ }^{(15)}$ In areas of high radiation damage (i.e., the first wall), temperatures would be held to $400^{\circ} \mathrm{C}$. This design then set coolant inlet and outlet temperatures at $77^{\circ} \mathrm{C}$ and $477^{\circ} \mathrm{C}$, respectively, for a He/steam system at a helium pressure of $60 \mathrm{~atm}$. (Note that these restrictions on temperature will have important implications on corrosion and spalling of oxide layers on stainless steel as will be discussed in Chapter 3.)

For the purpose of this design, it will be assumed that a $200^{\circ} \mathrm{C}$ temperature rise can be achieved in the reactor at 60 atms pressure while maintaining blanket temperatures near $500^{\circ} \mathrm{C}$. On inlet and outlet temperature of $300^{\circ} \mathrm{C}$ and $500^{\circ} \mathrm{C}$, respectively, will be used. For a specific heat of

$$
C_{p}=5.19(\text { watt } \cdot \mathrm{sec}) /\left(\mathrm{gm}^{\circ} \mathrm{C}\right)
$$

the helium mass flow rate required to remove $2,260 \mathrm{MW}_{\text {th }}$ is then $2.18 \times 10^{6}$ $\mathrm{gm} / \mathrm{sec}$. This flow will be proportioned to components as shown in Table 2 . The toroidal manifolds above and below the reactor will be assumed to be essentially divided into six segments, each serving nine ring elements as was shown in Figure 4. Flows along each toroidal segment will then reflect the addition or subtraction of ring segments. 
TABLE 2. Hel ium Flow by Component

\begin{tabular}{lrrrr}
\multicolumn{1}{c}{ Component } & Number & & $\begin{array}{l}\text { Hel ium Mass } \\
\text { Flow, gm } / \mathrm{sec}\end{array}$ \\
Blanket & 1 & & $2.18 \times 10^{6}$ \\
Steam Generator & 6 & & $3.63 \times 10^{5}$ \\
Ring Segment & 54 & & $4.03 \times 10^{4}$ \\
Module & 648 & & $3.36 \times 10^{3}$
\end{tabular}

Table 3 gives the thermal hydraulic information assumed for the blanket coolant loop. Pipe diameters and lengths are given, as well as temperature, pressure and all information on helium mass flows. The diffusion coefficient given is for a representative impurity in the helium with a mass number of 56 . The equations for both the diffusion and mass transfer coefficient are given in Chapter 4.

The steam generator in this case is modeled after that given for the gas cooled GA-DEMO. (14) The length and diameter are $12.5 \mathrm{~m}$ and $3.7 \mathrm{~m}$, respectively. The total surface area is $19,000 \mathrm{~m}^{2}$. Assuming inside tube diameters of 1.94 $\mathrm{cm}$ as with the blanket cooling tubes, this implies that there are 24,900 tubes in the generator.

No detailed model is available for the helium circulator. In applying the PAD code to the Peach Bottom reactor, the circulator was simply modeled by adding a length to the cold return duct to give an equivalent amount of surface area. (16) A $12 \mathrm{~m}$ length of cold return duct was used for the 40 MWe plant. A length of $35 \mathrm{~m}$ is used here.

Mass flow rates in the reactor blanket modules will now be determined. The required flow rates will depend on the heat load and effective heat transfer coefficient and surface area. The limits of helium cooling are set by allowable stresses in the first wa11. (17) Duct sizes in the GA-DEMO design were adjusted to keep helium velocities on the order of $15 \mathrm{~m} / \mathrm{sec}$ in the first wall. In that design, surface roughness techniques were assumed to give a heat transfer coefficient of 0.28 watts $/ \mathrm{cm}^{2} .{ }^{\circ} \mathrm{C}$. (18) With smooth walled tubes as used in the reference design here, the surface heat transfer coefficient $\mathrm{H}$, watts $/ \mathrm{cm}^{2} \cdot{ }^{\circ} \mathrm{C}$, is given by 


\section{TABLE 3. Blanket Coolant Loop Thermal Hydraulics}

\section{Dianieter, $\mathrm{cm}$
Length, m}

Temperature. " $\mathrm{C}$

Pressure, atm

Mass Flow, $9 \mathrm{~m} / \mathrm{sec}$

Velocity, $\mathrm{cm} / \mathrm{sec}$

Viscosity, $\mathrm{gm} / \mathrm{cm} \cdot \mathrm{se}$

$n=\frac{\text { Blanket Ring Header (Collection fram } n \text { Blanket Modules) }}{4} \frac{1}{4} \frac{\begin{array}{c}\text { Ring Header } \\ \text { to Toroidal } \\ \text { Manifold } \\ 12\end{array}}{1}$

Reynola's Number

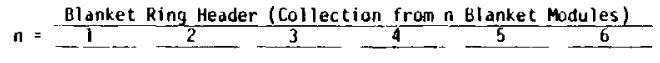
$\frac{1}{35}-\frac{2}{35}-\frac{3}{35}-\frac{4}{15}$

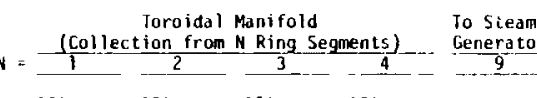

Steam

$\begin{array}{lllllll}35 & 35 & 35 & 35 & 35 & 35 & 50\end{array}$

$\begin{array}{cc}150 & 150 \\ 1.5 & 1.5 \\ 500 & 500\end{array}$

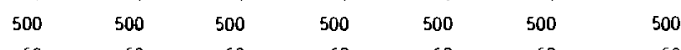

$60 \quad 60 \quad 60 \quad 60 \quad 60 \quad 60 \quad 60$

$\begin{array}{lllllll}3.36+3 & 6.72+3 & 1.01+4 & 1.34+4 & 1.68+4 & 2.02+4 & 4.03+4\end{array}$

$9.24+2 \quad 1.85+3 \quad 2.78+3 \quad 3.68+3 \quad 4.62+3 \quad 5.55+3 \quad 5.43+3$

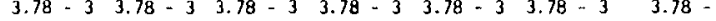

$3.76-4 \quad 3.76-4 \quad 3.76-4 \quad 3.76-4 \quad 3.76-4 \quad 3.76-4 \quad 3.76-4$

iffusion Coefficient $(M=56) \quad 4.46-2 \quad 4.46-2 \quad 4.46-2 \quad 4.46-2 \quad 4.46-24.46-24.46-2$

Schmidt Number $(M=56)$

$\begin{array}{lllllll}2.23 & 2.23 & 2.23 & 2.23 & 2.23 & 2.23 & 2.23\end{array}$

Mass Transfer Coefficient
$\operatorname{cm} / \sec (M=56)$

$\begin{array}{llll}2.37 & 2.97 & 3.56 & 4.12\end{array}$

Nuniber in whole Blanket

Total Area, $\mathrm{cm}^{2}$

54

Total Volume, $\mathrm{cm}^{3}$

$7.13+6$

$6.23+7$

$500 \quad 500-500 \quad 1.5 \quad 1.5 \quad 35$

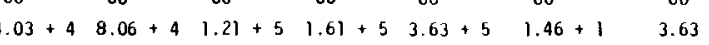

$\begin{array}{lllllll}6.03+2 & 1.21+3 & 1.81+3 & 2.41+3 & 3.06+3 & 1.14+3 & 2.27+3\end{array}$

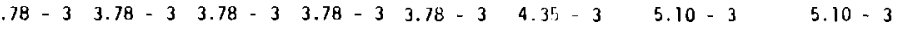

$\begin{array}{lllllllll}3.76-4 & 3.76-4 & 3.76-4 & 3.76-4 & 3.76-4 & 1.4 & 4 & 3.06-4 & 3.06-4\end{array}$

$\begin{array}{llllllll}9.10+5 & 1.82+6 & 2.73+6 & 3.63+6 & 6.15+6 & 2.74+4 & 7.55+6 & 7.55+6\end{array}$

$\begin{array}{llllllll}4.46-2 & 4.46-2 & 4.46-2 & 4.46-2 & 4.46-2 & 3.55-2 & 2.72-2 & 2.72-2\end{array}$

$\begin{array}{llllllll}2.23 & 2.23 & 2.23 & 2.23 & 2.23 & 2.22 & 2.21 & 2.21\end{array}$

$5.21-1 \quad 9.08-1 \quad 1.26 \quad 1.58 \quad 1.80-1.92-1.29$

$54 \quad 1$

$1.20+6$

$\begin{array}{llll}6 & 6 & 6 & 6 \\ 1.32+1 & 1.41+9 & 1.32+7 & 1.32+7\end{array}$

$5.30+7 \quad 6.36+7$

$\begin{array}{llll}6.60+8 & -.52+8 & 6.60+8 & 6.60+8\end{array}$

Rat Haniful

200

$63+5$

29

$6+8$ 


$$
\frac{H D}{k}=0.023\left(\frac{D v_{\rho}}{\mu}\right)^{0.8}\left(\frac{C_{p} \mu}{k}\right)^{0.33}
$$

where

$$
\begin{aligned}
D & =\text { channel diameter }, \mathrm{cm} \\
v & =\text { helium velocity, } \mathrm{cm} / \mathrm{sec} \\
k & =\text { helium thermal conductivity, watts } / \mathrm{cm} \cdot{ }^{\circ} \mathrm{C} \\
\rho & =\text { helium density, } \mathrm{gms} / \mathrm{cm}^{3} \\
\mu & =\text { helium viscosity, } \mathrm{gms} / \mathrm{cm} \cdot \mathrm{sec} \\
C_{p} & =\text { helium specific heat, watt } \cdot \mathrm{sec} / \mathrm{gm} \cdot{ }^{\circ} \mathrm{C}
\end{aligned}
$$

Using the helium properties at the inlet temperature of $300^{\circ} \mathrm{C}$ would indicate that a coolant velocity on the order of $40 \mathrm{~m} / \mathrm{sec}$ would be required to achieve a value of $H=0.28$ watts $/ \mathrm{cm}^{2} \cdot{ }^{\circ} \mathrm{C}$. At $15 \mathrm{~m} / \mathrm{sec}$, we get a value of $H \simeq$ 0.14 watts $/ \mathrm{cm}^{2} \cdot{ }^{\circ} \mathrm{C}$. The latter is likely the more realistic value.

The above heat transfer coefficient coupled with surface area and temperature difference will give the heat load which can be accepted. Previous calculations of the first wall and blanket coolant surface areas were put at $6.195 \times 10^{6}$ and $3.315 \times 10^{7} \mathrm{~cm}^{2}$, respectively. (19) With the desire here to maximize the surface area, a new estimate of $8.84 \times 10^{6} \mathrm{~cm}^{2}$ for the first wal1 will be made. With each tube in the first wall assumed to be $2.54 \mathrm{~cm}$ OD and $1.94 \mathrm{~cm} \mathrm{ID,} \mathrm{the} \mathrm{length} \mathrm{of} \mathrm{each} \mathrm{tube} \mathrm{would} \mathrm{be} \mathrm{required} \mathrm{to} \mathrm{be} \mathrm{approximately}$ $75 \mathrm{~cm}$. This is for 30 tubes per module with 648 modules. Referring to Figure 1 , this appears to be reasonable for the length of each tube. Likewise, the area of coolant channels in the blanket can be reasonably estimated to be 21.4 times the previous estimate. For the purposes of this examination, the coolant surface areas will be as shown below in Table 4 . The number of tubes per zone and their lengths are also given as estimated from Figure 1.

Assuming a somewhat unrealistic $200^{\circ} \mathrm{C}$ temperature differential for surface heat transfer, the first wall is then capable of removing approximately $248 \mathrm{MW}_{\text {th. }}$. The actual first wall heat load will consist of charge particle plasma losses and electron radiative losses (bremsstrahlung, etc.), as well as neutron and gamma energy deposition in the first wall region. Under steady 
TABLE 4. Coolant Channel Surface Area in 648 Modules

\begin{tabular}{|c|c|c|c|c|}
\hline & Zone & $\begin{array}{l}\text { Surface } \\
\text { Area }\left(\mathrm{cm}^{2}\right)\end{array}$ & $\begin{array}{c}\text { Tubes/ } \\
\text { Zone } \\
\end{array}$ & $\begin{array}{l}\text { Length } \\
\left(\mathrm{cm}^{2}\right) \\
\end{array}$ \\
\hline (First Wall) & 3 & $8.84 \times 10^{6}$ & 30 & 75 \\
\hline (Blanket) & 5 & $3.38 \times 10^{7}$ & 90 & 95 \\
\hline (Blanket) & 7 & $1.07 \times 10^{7}$ & 30 & 90 \\
\hline (Blanket) & 9 & $5.53 \times 10^{6}$ & 20 & 70 \\
\hline
\end{tabular}

state operation, the conduction and convection charged particle losses plus radiative losses would equal the alpha power of 353 MW given in Table 1 . There appears to be some discrepancy in the power balance for the above terms in the ORNL design report, but the ratio of conduction losses to alpha power given will be used. This puts the radiative losses at $45 \mathrm{MW}$ and charged particle losses at $308 \mathrm{MW}$.

To calculate the actual heat load in the first wall region due to neutron and gamma radiation, the neutron fluxes by group and space point must be matched with the appropriate kerma factors. As a first estimate here, it will be simply assumed that this heating term in the first wall is approximately $10 \%$ of the total neutron power output as was the case in the UWMAK-II design, (2) or 142 MW.

The first wa11 then sees a minimum of $187 \mathrm{MW}$, and up to $495 \mathrm{MW}$ depending on magnetic divertor efficiency and the fraction of charged particle losses hitting the wal1. Limiting the heat load to $248 \mathrm{MW}$ would require an $80 \%$ efficient divertor, which is reasonable. It is believed that a divertor is necessary if helium cooling in the first wall is to be used.

Assuming an average coolant temperature of $400^{\circ} \mathrm{C}$ in the first wall, the corresponding density at $60 \mathrm{~atm}$ is then $4.346 \times 10^{-3} \mathrm{gm} / \mathrm{cm}^{3}$ with a velocity of $15 \mathrm{~m} / \mathrm{sec}$. The mass flow in 30 tubes is $5.78 \times 10^{2} \mathrm{gm} / \mathrm{sec}$ or $1.927 \times 10^{1}$ $\mathrm{gm} / \mathrm{sec}$ in each individual tube.

The resulting therma 1 hydraulic parameters for the first wall and blanket modules are given in Table 5. The flow rates for the blanket were derived as 
TABLE 5. Blanket Module Thermal Hydraulics

Diameter, $\mathrm{cm}$

Length, $\mathrm{cm}$

Temperature (avg), ${ }^{\circ} \mathrm{C}$

Pressure, atm

Mass Flow, $\mathrm{gm} / \mathrm{sec}$

Velocity, cm/ $/ \mathrm{sec}$

Density, $\mathrm{gm} / \mathrm{cm}^{3}$

Viscosity, $\mathrm{gm} / \mathrm{cm} \cdot \mathrm{sec}$

Reynold's Number

Diffusion Coefficient $(M=56)$

Schmidt Number $(M=56)$

Mass Transfer Coefficient,

$\mathrm{cm} / \mathrm{sec}(M=56)$

No. in Whole Blanket

Total Area, $\mathrm{cm}^{2}$

Total Volume, $\mathrm{cm}^{3}$

\begin{tabular}{|c|c|}
\hline & Module Cool \\
\hline 3 & 5 \\
\hline 1.94 & 1.94 \\
\hline 75 & 95 \\
\hline 400 & 400 \\
\hline 60 & 60 \\
\hline $1.927+1$ & $2.18+1$ \\
\hline $1.5+3$ & $1.70+3$ \\
\hline $4.35-3$ & $4.35-3$ \\
\hline $3.43-4$ & $3.43-4$ \\
\hline $3.69+4$ & $4.17+4$ \\
\hline $3.55-2$ & $3.55-2$ \\
\hline 2.22 & 2.22 \\
\hline 2.47 & 2.72 \\
\hline
\end{tabular}

$\begin{array}{cc}1.94 & \frac{9}{7} \\ 90 & 70\end{array}$

$400 \quad 400$

$60 \quad 60$

$2.18+12.18+1$

$1.70+3 \quad 1.70+3$

$4.35-3 \quad 4.35-3$

$3.43-4 \quad 3.43-4$

$4.17+4 \quad 4.17+4$

$3.55-2 \quad 3.55-2$

2.22

2.22

$2.72 \quad 2.72$

$30 \quad 90$

$19,440 \quad 58,320$

30

$8.89+6 \quad 3.38+7$

$19,440 \quad 12,960$

12,960

$\begin{array}{ll}1.07+7 & 5.53+6 \\ 5.17+6 & 2.68+6\end{array}$

$1.64+7$

$2.68+6$

$\frac{\text { Internal Collection by Zone }}{5}$ 9-

80

Module

Exhaust

20

15

500

$500 \quad 500$

$\begin{array}{lllll}60 & 60 & 60 & 60 & 60\end{array}$

$\begin{array}{lllll}5.78+2 & 1.96+3 & 6.54+2 & 4.36+2 & 3.63+3\end{array}$

$\begin{array}{lllll}3.46+3 & 1.17+4 & 3.92+3 & 2.61+3 & 3.06+3\end{array}$

$\begin{array}{lllll}3.78-3 & 3.78-3 & 3.79-2 & 3.78-3 & 3.78-3\end{array}$

$\begin{array}{lllll}3.76-4 & 3.76-4 & 3.76-4 & 3.76-4 & 3.76-4\end{array}$

$\begin{array}{lllll}2.61+5 & 8.85+5 & 2.95+5 & 1.97+5 & 6.15+5\end{array}$

$4.46-2 \quad 4.46-2 \quad 4.46-2 \quad 4.46-2 \quad 4.46-2$

$\begin{array}{lllll}2.23 & 2.23 & 2.23 & 2.23 & 2.23\end{array}$

3.84

$1.02+$

4.24

$\begin{array}{ccccc}1 & 1 & 1 & 1 & 1\end{array}$

$\begin{array}{lllll}648 & 648 & 648 & 648 & 54\end{array}$

$1.22+6 \quad 8.40+5 \quad 4.58+5 \quad 2.29+5 \quad 8.11+5$

$\begin{array}{lllll}2.29+6 & 1.57+6 & 8.59+5 & 4.29+5 & 3.05+6\end{array}$ 
above to remove the additional 1,765 MW (1,280 MW neutron, 485 exothermic) deposited in the blanket. Examples in Table 5 are again given for the diffusion coefficient, Schmidt number and mass transfer coefficient based on an impurity of mass number 56 . 
· 


\subsection{SOURCE TERMS}

In this chapter we shall be identifying mechanisms for release of activation products into the coolant loop just presented. Release rates will be established for input into transport and deposition models. First, equilibrium activation product inventories in the blanket will be given.

\section{BLANKET ACTIVATION}

The generation of activation products in blanket structural materials for the design presented in this report has previously been examined by Willenberg and Bickford. ${ }^{(4)}$ The neutronics model used in that analysis divided the blanket up into various zones, as shown in Figure 7 . This is the source of the zone designations used for the cooled first wall and blanket regions as given in the previous section.

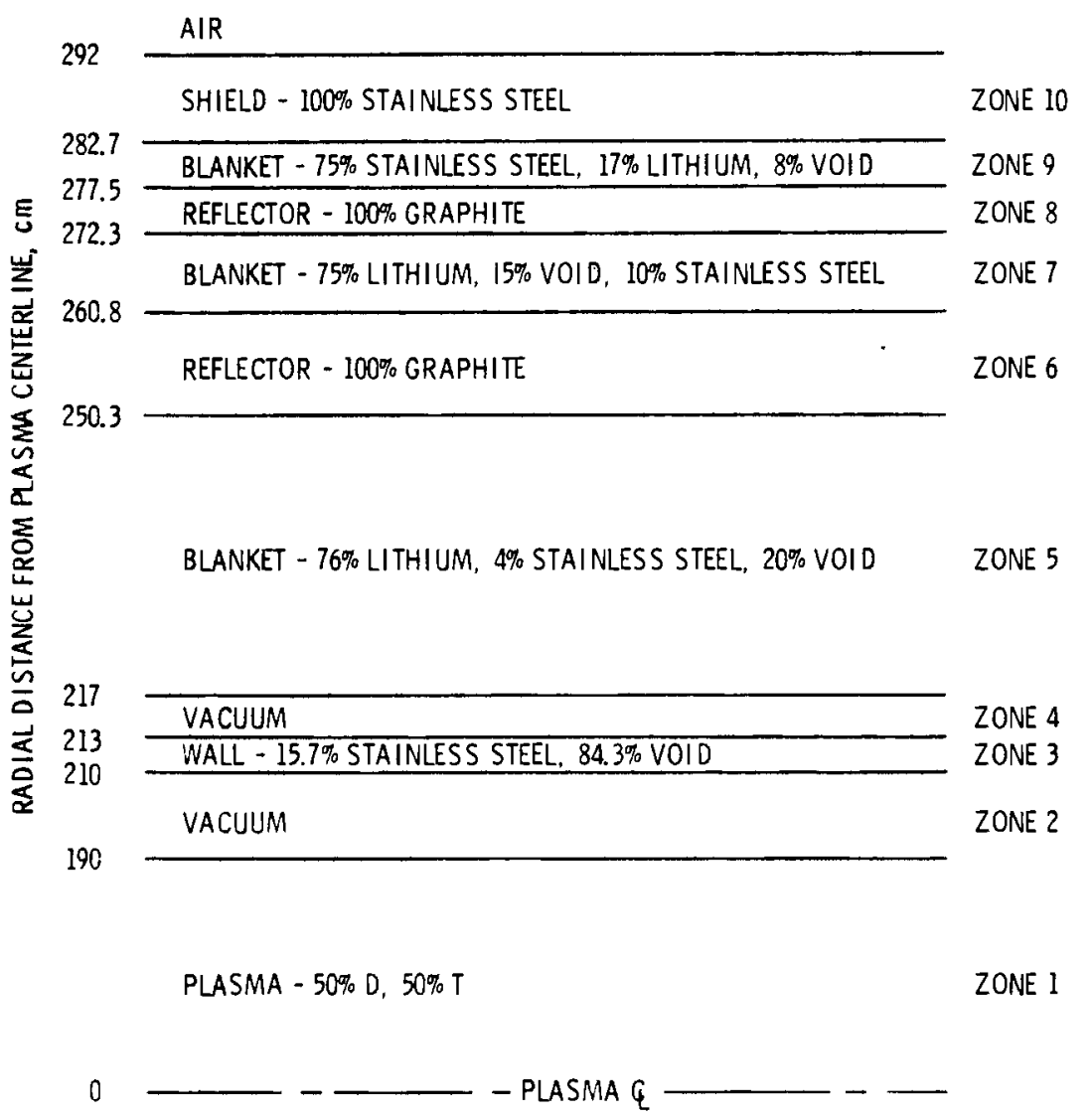

FIGURE 7. Blanket Neutronics Mode1 
The neutron flux in the above reference was calculated using the discrete ordinates method. The ANISN computer code ${ }^{(21)}$ was used in cylindrical geometry. The blanket was treated as an infinitely long cyclinder with circular crosssection, and the one-dimensional neutron transport equation was solved with a $\mathrm{P}_{3}-\mathrm{S}_{8}$ approximation. The neutron spectrum was divided into 30 energy groups. The GLUCKE computer code ${ }^{(22)}$ was used to calculate the activation product inventories in the blanket. This code reads the 30 -group neutron fluxes calculated by ANISN, processes these with activation cross-section and decay data, and calculates the activation rates for the various radionuclides. The equilibrium inventories predicted for the stainless steel cooling tubes are given in Reference 4.

\section{NUCLEAR SPUTTERING}

A later examination of this reference design by Bickford $(19)$ identified the neutron sputtering of activation products into the blanket coolant tubes. This included the bulk removal of activation products from channel surfaces by lattice dynamic neutron sputtering as well as direct daughter recoil emission of radionuclides from $(n, x)$-type reactions in the channel walls.

The rate of ejection of atoms by lattice dynamic or bulk neutron sputtering was calculated using the theory described by Sigmund. (23) According to this theory, sputtering from a target surface is the result of cascades of atomic collisions with ejection of atoms with sufficient energy to overcome the surface binding forces. For transmission sputtering by a beam of fast neutrons, Sigmund determines the number of atoms sputtered per incident neutron as

$$
N=\Lambda N \sigma(E)\langle\nu(E)\rangle
$$

where

$$
\begin{aligned}
\Lambda= & \text { property of the target material and the state of the surface } \\
N= & \text { target atom density } \\
\sigma(E)= & \text { total cross-section of a neutron with energy } E \\
\langle\nu(E)>= & \text { average of the energy not lost to ionization during the slowing- } \\
& \text { down process averaged over the spectrum of recoil energies. }
\end{aligned}
$$


The rate of ejection of radionuclide daughter products of $(n, \alpha),(n, p)$, $(n, 2 n)$ and other reactions from metal surfaces is based on a model developed by Lessor, Thomas and Harling. ${ }^{(24)}$ Here, the recoiling daughter products from the $(n, x)$-type reactions are assumed to propagate on the average in a straight line with a definite distance-vs.-energy relationship. With this model, the rate of daughter product nuclei ejection per unit area and time from a surface by a neutron flux $\Phi$ is

$$
\dot{N}=\Phi n_{t} \int_{0}^{x} \max d x \int_{\mu(x)}^{+1} \frac{d \sigma}{d\left(\cos \theta^{c m}\right)} d\left(\cos \theta^{c m}\right)
$$

where

$$
\begin{aligned}
\mathrm{n}_{t}= & \text { number density of target species in material } \\
\mathrm{x}_{\max }= & \text { maximum distance from surface for which a recoiling daughter } \\
& \text { could escape } \\
\mathrm{d} \sigma / \mathrm{d}\left(\cos \theta^{\mathrm{cm}}\right)= & \text { differential solid-angle scattering cross-section } \mathrm{d} \sigma / \mathrm{d} \Omega \\
& \text { in the center of mass frame about the incident neutron } \\
& \text { direction } \\
\mu(\mathrm{x})= & \text { integration } 1 \text { imit } \cos \theta_{\mathrm{c}}^{\mathrm{cm}}(\mathrm{x}) \\
\Phi= & \text { neutron flux, assumed normal to surface. }
\end{aligned}
$$

The validity of these models and the status of experimental data are discussed by Bickford in Reference 19. In general, the current experimental sensitivities and signal to background ratios during analysis are only sufficient to put an upper bound on yields from dynamic lattice neutron sputtering. The experimental data for direct daughter recoil sputtering is much more conclusive. And at the wall loadings of interest, it was predicted that the latter source exceeds that due to lattice dynamic neutron sputtering by a factor of approximately $6,{ }^{(25)}$ which agrees with the other reported results. (26) The use of the model by Lessor, et al. for direct daughter recoiled then should give a good estimate of source terms due to sputtering.

The magnitude of the source terms predicted in Reference 19 for this reactor are given in Table 6 . The units of atoms $/ \mathrm{cm}^{2} \cdot \mathrm{sec}$ sputtered from the 
TABLE 6. Radionuclide Source Terms

\begin{tabular}{|c|c|c|c|c|}
\hline \multirow[b]{3}{*}{ Nucl ide } & \multicolumn{4}{|c|}{ Source Term, Atoms $/\left(\mathrm{cm}^{3} \cdot \mathrm{sec}\right)$} \\
\hline & & & & \\
\hline & 3 & 5 & 7 & 9 \\
\hline${ }^{51} \mathrm{Cr}$ & $1.98+7$ & $9.47+6$ & $5.88+5$ & $1.99+5$ \\
\hline${ }^{54} \mathrm{Mn}$ & $2.13+7$ & $1.32+6$ & $8.32+5$ & $2.84+5$ \\
\hline $56_{\mathrm{Mn}}$ & $2.89+7$ & $5.40+6$ & $1.46+6$ & $5.07+5$ \\
\hline${ }^{57} \mathrm{Co}$ & $2.97+7$ & $8.11+6$ & $8.34+5$ & $2.76+5$ \\
\hline${ }^{58} \mathrm{Co}$ & $2.37+7$ & $1.13+7$ & $1.63+6$ & $5.63+5$ \\
\hline${ }^{60} \mathrm{Co}$ & $9.65+6$ & $7.01+6$ & $1.79+5$ & $5.03+4$ \\
\hline${ }^{99} \mathrm{Mo}$ & $5.41+5$ & $1.93+5$ & $2.75+4$ & $1.04+4$ \\
\hline
\end{tabular}

wall have been corrected by a factor of coolant channel perimeter divided by area $(=4 / D)$ to give a source term to the coolant stream in the units of atoms $/ \mathrm{cm}^{3} \cdot \mathrm{sec}$.

CORROSION

Corrosion of coolant channel walls and subsequent bulk removal of activation products by spalling or mechanical abrasion is a possible source term for radionuclides in the coolant stream. However, the expected operating conditions for the reference fusion reactor will minimize the importance of this term.

Stainless steel type 316 is known to exhibit surface oxidation in high temperature, low-oxygen potential environments as might be expected in helium cooled fission or fusion reactors. Although this problem has been investigated for some time, some inconsistency remains in the reported results, with some showing an iron rich oxide as opposed to the usual chromium oxide layer. At temperatures of $650^{\circ} \mathrm{C}$ or above, the formation of a thin oxide scale in helium with expected impurity levels $\left(\mathrm{CO}, \mathrm{H}_{2}, \mathrm{~N}_{2}\right.$, etc.) becomes measurable. $(29,30)$ However, at reduced temperatures, the interaction drops off sharply. Oxidation of stainless steels even in steam atmospheres up to $1,100^{\circ} \mathrm{F}\left(593^{\circ} \mathrm{C}\right)$ has been shown to be negligible. (31) 
In the reference design under consideration here, a number of factors are expected to reduce the importance of oxide formation and spalling. First, carbon and carbon compounds and particulates such as found in HTGRs will not be present due to the lack of graphite structures exposed directly to the coolant stream in the fusion reactor. Mechanical abrasion by particulates should be eliminated. Second, proper handling, cleaning, and preparation of materials for use in the reactor can eliminate the formation of oxide scale before operation. And third, operation at temperatures only slightly above $500^{\circ} \mathrm{C}$ should significantly reduce or el iminate oxide film formation and subsequent spalling.

Because of the above factors, corrosion is expected to be negligible. However, as a check, an estimate of possible corrosion can be made based on a linear extrapolation of corrosion rates at higher temperatures down to $550^{\circ} \mathrm{C}$. This is shown in Table 7 for stainless stee 1 type 316 in a controlled impurity helium exposure as reported by Rosenwasser and Johnson. $(30)$ The weight gain was assumed to be due to a uniform layer of $\mathrm{Cr}_{2} \mathrm{O}_{3}\left(5.21 \mathrm{gm} / \mathrm{cm}^{3}\right)$.

Assuming a steady state spalling of the corrosion layer, a wall removal rate of $8.82 \times 10^{-14} \mathrm{~cm} / \mathrm{sec}$ is predicted at $550^{\circ} \mathrm{C}$. This compares to a removal rate of $1.31 \times 10^{-13} \mathrm{~cm} / \mathrm{sec}$ in the first wall (Zone 3) by lattice dynamic neutron sputtering predicted by Bickford for this design, $(25)$ as shown in Table 8. Also shown in Table 8 are effective removal rates predicted for various radionuclides by direct daughter recoil sputtering. This latter term is, of course, not a true wall removal rate, but a selective removal of atoms. Its purpose is simply to show how sputtering is expected to dominate the extrapolated corrosion rate at $550^{\circ} \mathrm{C}$.

TABLE 7. Corrosion of Type 316 SS in Hel ium

\begin{tabular}{|c|c|c|c|}
\hline $\begin{array}{c}\text { Temperature } \\
{ }^{\circ} \mathrm{C}\end{array}$ & $\begin{array}{l}\text { Weight Ga in } \\
\mathrm{mg} / \mathrm{cm}^{3}\end{array}$ & $\begin{array}{l}\text { Exposure } \\
\text { Hours }\end{array}$ & $\begin{array}{c}\text { Penetration } \\
\mathrm{cm} / \mathrm{sec}\end{array}$ \\
\hline 800 & 0.13 & 4,000 & $1.73 \times 10^{-12}$ \\
\hline 650 & 0.07 & 5,000 & $7.46 \times 10^{-13}$ \\
\hline $\begin{array}{l}500 \\
\text { (estimated) }\end{array}$ & & & $8.82 \times 10^{-14}$ \\
\hline
\end{tabular}


TABLE 8. Estimated Sputtering Removal Rates (25)

\begin{tabular}{lc} 
& $\begin{array}{r}\text { First Wal1 Removal } \\
\text { Rate, cm/sec }\end{array}$ \\
\cline { 2 - 2 } Lattice Dynamic Neutron Sputtering & $1.31 \times 10^{-13}$ \\
Direct Daughter Recoil Sputtering & \\
${ }^{54}{ }_{\mathrm{Mn}}$ & $2.50 \times 10^{-13}$ \\
${ }^{56}{ }_{\mathrm{Mn}}$ & $6.60 \times 10^{-10}$ \\
${ }^{57} \mathrm{Co}$ & $2.80 \times 10^{-13}$ \\
${ }^{58} \mathrm{Co}$ & $9.60 \times 10^{-13}$ \\
${ }^{60} \mathrm{Co}$ & $3.60 \times 10^{-14}$ \\
${ }^{51} \mathrm{Cr}$ & $2.90 \times 10^{-12}$ \\
${ }^{99} \mathrm{Mo}$ & $7.50 \times 10^{-12}$
\end{tabular}

The formation of oxide layers on the surface of stainless steel would significantly change the atom constituency of the steel near the surface. The atom densities would differ from the underlying alloy substrate which would impact all neutronics and sputtering calculations. The assumption of negiigible corrosion allows the use of the previously calculated sputtering data from clean stainless steel under plausible conditions.

\section{EVAPORATION}

The final source term considered for release of activation products into the coolant stream is evaporation. However, the activation products of interest as well as the constituents of stainiess steel have extremely low vapor pressures at the expected operating temperature as shown in Figure 8 . Evaporation is not expected to present a serious source term of radionuclides to the coolant stream. Both iodine and cesium are also shown in Figure 8 as a comparison to typical fission product radionuclides possible in HTGR coolant streams. 


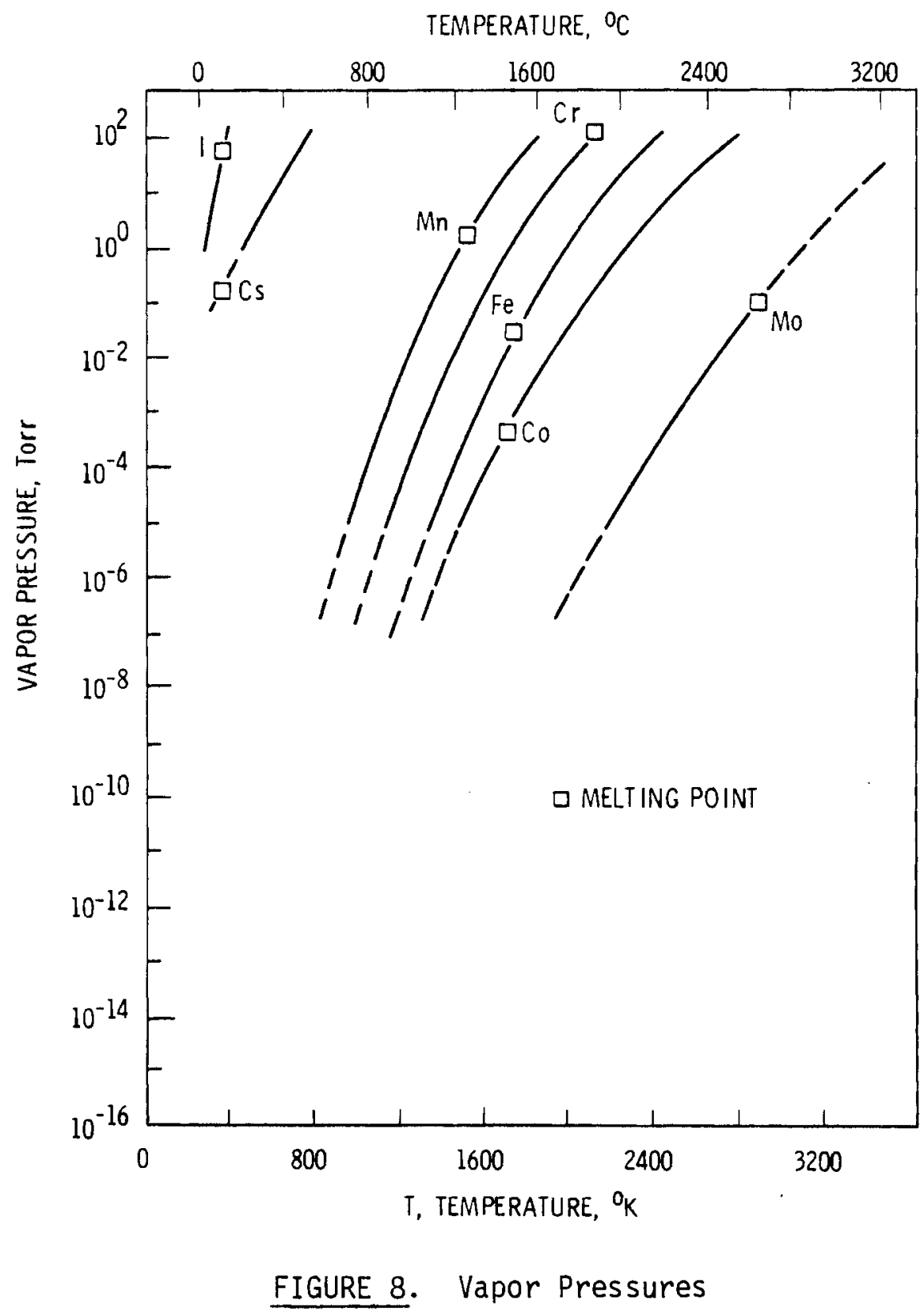

In conclusion, nuclear sputtering by direct daughter recoil emission is expected to be the dominant source term of radionuclides ejected into the reference coolant loop. The transport modeling techniques to be used will now be presented. 
.

· 


\subsection{MODELING}

In this chapter, the techniques used to model transport and deposition of activation products will be presented, as well as the model for contact dose calculations.

\section{TRANSPORT MODELING}

A number of computer models have been developed to examine fission product transport in the primary coolant of HTGRs. These include the PAD ${ }^{(6)}$ and PADLOC ${ }^{(7)}$ codes mentioned previously, as well as others such as SUVIUS, (32) ADDICT-2, ${ }^{(33)}$ and EVAP. ${ }^{(34)}$ In general, the model must account for the following:

- sources in the coolant,

- sources on the channel surfaces,

- plateout on the surfaces,

- desorption from the surfaces,

- convection along the flow path,

- decay of radionuclides.

For flow along a coolant channel of regular geometry, the model typically consists of a mass balance on the radionuclide of interest. A simplification to assume only one dimension is typically used, with the physical parameters coolant velocity, pressure, temperature, and radionuclide concentration allowed to vary only along the direction of flow. The mass transport equations presented here have been modeled in the PAD and PADLOC codes, both of which were developed at General Atomic to predict fission product transport in gas cooled reactors. The PAD code utilizes an explicit time integration method to solve the equations which makes short time steps necessary to avoid numerical instability problems. It is also only capable of analyzing flow in a single closed loop geometry. The more sophisticated PADLOC code employs an implicit solution method and is capable of modeling an arbitrary coolant system when presented as a branch network. This will be applicable to the branch network presented for the reference design in Chapter 2. 
With coolant velocities typically several tens of meters per second in gas cooled systems, the coolant can be assumed to be well mixed across the coolant channel. The impurity concentration in the flowing gas can then be described by a bulk concentration $c(x, t)$, atoms $/ \mathrm{cm}^{3}$. An appreciable concentration gradient appears only in a thin boundary layer near the channel surface, denoted as $B(x, t)$, atoms $/ \mathrm{cm}^{3}$. This boundary layer concentration is related to the surface concentration $S(x, t)$, atoms $/ \mathrm{cm}^{3}$, by the vapor pressure of the impurity over the channel surface. This is denoted by

$$
B(x, t)=\frac{A_{0}}{R T} P(S(x, t), T)
$$

where

$$
\begin{aligned}
A_{0} & =\text { Avogadro's number, atoms } / \mathrm{g} \cdot \mathrm{mole} \\
R & =\text { gas constant, } \mathrm{cm}^{3} \cdot \mathrm{atm} /\left(\mathrm{g} \cdot \mathrm{mole}{ }^{\circ} \mathrm{K}\right) \\
T & =\text { surface temperature, }{ }^{\circ} \mathrm{K} \\
P & =\text { vapor pressure, atom. }
\end{aligned}
$$

The vapor pressure is then determined by assuming an appropriate sorption mechanism for the release of impurities from the surface. This sorption mechanism can be highly dependent on the specific impurity as well as surface conditions (roughness, oxidation, etc.).

The net diffusion of impurities through the boundary layer will then present either the coolant or the surface with a positive source term, depending on the direction of impurity transfer. By convention, the flux will be considered positive when directed towards the coolant. The flux is then calculated as

$$
\text { flux }=h(x, t)[B(x, t)-C(x, t)], \frac{\text { atoms }}{\mathrm{cm}^{2} \cdot \sec }
$$

where

$$
h=\text { gas-phase mass transfer coefficient, } \mathrm{cm} / \mathrm{sec} \text {. }
$$

The value of $h$ is predicted by empirical equations similar to those for heat transfer and depends on the diffusion coefficient, channel diameter and dimensionless parameters such as Reynolds number, Schmidt number, Grashof number, etc. 
To develop a mass balance for a specific radionuclide, direct surface source terms such as from neutron activation of parent nuclides must be identified. These are denoted here as $\dot{q}_{s}(x, t)$, atoms $/\left(\mathrm{cm}^{2} \cdot \mathrm{sec}\right)$. Accounting for radioactive decay, the differential equation to express the surface concentration is then

$$
\frac{\partial S(x, t)}{\partial t}=\dot{q}_{S}(x, t)-h(x, t)[B(x, t)-C(x, t)]-\lambda S(x, t) .
$$

The source term into the coolant stream already mentioned is that due to desorption of activation products from the plateout surface, or

$$
\text { Source rate }=\frac{P(x)}{A(x)} h(x, t)[B(x, t)-C(x, t)]
$$

where

$$
\begin{aligned}
& P(x)=\text { wetted perimeter, } \mathrm{cm} \\
& A(x)=\text { cross-sectional area, } \mathrm{cm}^{2} .
\end{aligned}
$$

Any addition source due to direct injection of radionuclides into the coolant will be denoted by $\dot{q}_{c}(x, t)$, atoms $/\left(\mathrm{cm}^{3} \cdot \mathrm{sec}\right)$. These will be the sputtering source terms discussed in Chapter 3.

Removal of activation products from the coolant must account for decay as well as axial convection. If the number of activation product atoms entering a volume element $A(x) d x$ at position $x$ per unit time is

$$
\Phi(x)=v(x, t) A(x) C(x, t)
$$

where

$$
v(x, t)=\text { coolant velocity }
$$

then the net removal rate per unit volume can be expressed as

$$
\frac{1}{A(x)} \frac{\partial \Phi}{\partial x}=v(x, t) \frac{\partial C(x, t)}{\partial t}+\left[\frac{\partial v(x, t)}{\partial x}+\frac{v(x, t)}{A(x)} \frac{d A(x)}{d x}\right] C(x, t) \text {. }
$$

Collecting all source and removal terms, the coolant concentration can be expressed as

$$
\begin{aligned}
\frac{\partial C(x, t)}{\partial t}= & \dot{q}_{C}(x, t)+\frac{P(x)}{A(x)} h(x, t)[B(x, t)-C(x, t)] \\
& -v(x, t) \frac{\partial C(x, t)}{\partial x}-\Lambda_{C}(x, t) C(x, t)
\end{aligned}
$$


where

$$
\Lambda_{c}(x, t)=\lambda+\frac{\partial V(x, t)}{\partial x}+\frac{v(x, t)}{A(x)} \frac{d A(x)}{d x} .
$$

The term $\Lambda_{c}(x, t)$ represents an effective decay constant for the coolant concentration including convection and normal radioactive decay.

COUPLED COOLANT-SURFACE CONCENTRATION EQUATION

To completely describe the problem, the functional relationship for the boundary layer must be defined, as well as initial values for surface and coolant concentrations and boundary conditions for unclosed systems. The complete set of equations for a length of coolant channel is then

$$
\begin{aligned}
& \frac{\partial C(x, t)}{\partial t}=\dot{q}_{C}(x, t)+\frac{P(x)}{A(x)} h(x, t)[B(x, t)-C(x, t)] \\
& -v(x, t) \frac{\partial C(x, t)}{\partial x}-\Lambda_{C}(x, t) C(x, t) \\
& \frac{\partial S(x, t)}{\partial t}=\dot{q}_{S}(x, t)-h(x, t)[B(x, t)-C(x, t)]-\lambda S(x, t) \\
& B(x, t)=f[S(x, t)] \\
& C(x, 0)=C_{0}(x) \\
& S(x, 0)=S_{0}(x) \quad \text { Initial Conditions } \\
& C(0, t)=C_{x=0}(t) \quad \text { Boundary Condition }
\end{aligned}
$$

In this initial examination of the problem of mass transfer in a gas cooled fusion reactor, the steady state solution shall be described. This will give the maximum inventories in the fusion system.

In addition, the assumption will be made that the vapor pressures are sufficiently low for the activation products of interest that the surfaces 
will act as a perfect sink for deposition. This is equivalent to assuming $B(x) \ll C(x)$. This will be discussed more fully below. Solving Equations 10 and 11 for this assumption and for $\frac{\partial}{\partial t}=0$ gives

$$
c(x)=\frac{\dot{q}_{c}}{a v}\left[1-e^{-a x}\right]+c_{0} e^{-a x}
$$

and

$$
S(x)=\frac{1}{\lambda}\left[\dot{q}_{s}+h \cdot c(x)\right]
$$

where

$$
a=\frac{1}{V}\left(\lambda+\frac{P}{A} h\right)
$$

These equations will be used here to predict the transport of activation products.

\section{MASS TRANSFER COEFFICIENT}

For forced convection in coolant channels, the mass transfer coefficient $\mathrm{h}, \mathrm{cm} / \mathrm{sec}$, is calculated as

$$
h=\frac{D}{d}\left[a_{1}+a_{2}\left(\frac{d}{L}\right)^{a_{3}} \cdot \operatorname{Re}^{a_{4}}\right] \cdot s_{c}^{a_{5}}
$$

where

$$
\begin{aligned}
D & =\text { diffusion coefficient of activation product in helium, } \mathrm{cm}^{2} / \mathrm{sec} \\
\operatorname{Re} & =\text { Reynolds number } \\
\mathrm{Gr} & =\text { Grashof number } \\
\mathrm{d} & =\text { hydraulic diameter of channe } 1, \mathrm{~cm} \\
L & =\text { Hydrodynamic entry length, cm }
\end{aligned}
$$

The constants $a_{1}$ through $a_{5}$ are determined by the specific geometry and flow conditions involved. The reference design to be presented will utilize turbulent annular flow in tubes and large conduits of circular cross-section. For this case, the values are 
$a_{1}=0, a_{2}=0.023, a_{3}=0, a_{4}=0.8$, and $a_{5}=0.33 .(7)$

The diffusion coefficient $D$ given in Equation 17 is calculated as

$$
\mathrm{D}\left(\frac{\mathrm{cm}^{2}}{\mathrm{sec}}\right)=0.1682\left(\frac{T_{c}}{1000}\right)^{1.65} \cdot\left(\frac{23.83}{\mathrm{P}}\right) \cdot\left(\frac{1 / \mathrm{M}+0.25}{0.257}\right)^{1 / 2}
$$

where

$$
\begin{aligned}
T_{C} & =\text { coolant temperature, }{ }^{\circ} \mathrm{K} \\
P & =\text { coolant pressure, atm } \\
M & =\text { molecular weight of impurity, gm/mole. }
\end{aligned}
$$

\section{MODEL VALIDITY}

The methods used in the PAD and PADLOC computer codes have been used successfully to predict the transport and deposition of radionuclides in several systems. These include the General Atomics ${ }^{(35)}$ and Battelle Memorial Institute deposition loop, ${ }^{(36)}$ as well as Peach Bottom, Fort St. Vrain, and the Pegase test reactor in France. ${ }^{(37)}$ The results indicate that the codes are capable of good agreement with experimentally measured plateout activities. This is especially true for radionuclides with relatively low vapor pressures such as Ce-144, Zr-95, Ru-103, and Te-129 where the surfaces in the coolant system could be treated as a perfect sink for deposition. (30) For more volatile elements such as I-131 and Cs-137, the codes are capable of predicting plateout distributions given accurate sorption data to determine vapor pressures.

In this paper, the source terms of interest will be activation products from the coolant channel walls, assumed here to be stainless steel type 316 . As discussed previously, the activation products as well as the constituents of the steel itself have extremely low vapor pressures under the expected operating temperatures. Under these conditions, sticking probabilities for material transported back to the wall should be excellent. Desorption can be neglected and the walls can be considered a perfect sink. 
In light of the extremely low vapor pressures involved and the previous acceptable modeling of transport and deposition of Ce-144, Ru-133 and others with the above assumption, the mass transfer equations presented here should be applicable to the fusion reactor environment.

It is unknown at present what effect, if any, the presence of large magnetic fields will have on the transport and deposition of material in the cooling system. Material ejected by the sputtering process is for the most part in the form of neutral atoms which are not influenced by the magnetic fields. Direct daughter recoil products produced near the surface of the coolant channel can be ejected with energies as high as several MeV. However, the subsequent stopping and recombination distance in helium at 60 atm will be much smaller than the channel diameter. It is felt at this time that effects of magnetic fields can be neglected and the transport models can be used as presented.

\section{CONTACT DOSE RATE}

Contact dose rates on the surface of various pipe runs will be calculated using the ISOSHLD computer code. $(39,40)$ The cylindrical geometry option will be used for the various pipe runs, with the dose point off the side of the pipe between the endpoints assumed. Gamma source strengths and energies were taken from Reference 41. 
. 


\subsection{CALCULATIONS}

The source terms given in Table 9 as predicted in PNL-2942 were used to determine atom inventories in the coolant (atoms $/ \mathrm{cm}^{3}$ ) and on the surface of the channel walls (atoms $/ \mathrm{cm}^{2}$ ). These include the sputtering inputs from both direct daughter and lattice dynamic neutron sputtering. Equations 15 and 16 were then solved for each coolant branch in succession using the appropriate flow parameters as well as diffusion and mass transfer coefficients for each radionuclide. The sputtering source terms exist only for coolant channels in the blanket module itself. Beyond that, the coolant concentrations at the end of one branch provide the initial concentration at the start of the next branch. At junctions of two or more branches, the concentrations are determined by a continuity of atom flow rates. That is,

$$
C A v=\sum C_{i} A_{i} v_{i}
$$

where

$$
\begin{aligned}
& A=\text { cross-sectional area } \\
& v=\text { coolant velocity. }
\end{aligned}
$$

The average inventories in the branches were determined by integrating Equations 15 and 16 over the length $L$ of the branch. In the blanket module where source terms are present, the average is then

$$
\bar{c}=\frac{\dot{q}_{c}}{a v}\left[1-\frac{1}{a L}\left(1-e^{-a L}\right)\right] \text {. }
$$

In the rest of the coolant loop, the average inventory in the coolant was calculated as

$$
\bar{C}=\frac{C_{0}}{a v}\left(1-e^{-a L}\right) \text {. }
$$

The areas and volumes for the various branches as given in Tables 3 and 5 were then used to determine the predicted inventories in curies in the coolant and on the surface of each branch. These could be summed and compared to the actual equilibrium activities for the source terms given in Table 9 as a check on mathematical errors in the calculations. 
TABLE 9. Source Terms by Blanket Zone

\begin{tabular}{|c|c|c|c|c|c|c|c|c|c|c|c|}
\hline \multirow[b]{2}{*}{ Radionuclide } & \multicolumn{4}{|c|}{ Atums $/ \mathrm{cm}^{3} \cdot \mathrm{sec}$} & \multicolumn{5}{|c|}{$\mathrm{Ci} / \mathrm{sec}$} & \multirow{2}{*}{$\begin{array}{l}\text { Total } \\
\mathrm{Ci} / \mathrm{sec} \\
\end{array}$} & \multirow[b]{2}{*}{ Equilibrium $C i$} \\
\hline & Zone 3 & Zone 5 & Zone 7 & Zone 9 & Zone 3 & Zone 5 & Zone & & Zone 9 & & \\
\hline${ }^{56} \mathrm{Mn}$ & $2.89+7$ & $1.05+7$ & $1.46+6$ & $5.07+5$ & $2.51-1$ & $3.47-1$ & 1.52 & -2 & $2.74-3$ & $6.16-1$ & $8.25+3$ \\
\hline${ }^{58} \mathrm{Co}$ & $2.37+7$ & $1.01+7$ & $1.63+6$ & $5.63+5$ & $3.13-4$ & $5.07-4$ & 2.58 & -5 & $4.62-6$ & $8.50-4$ & $7.50+3$ \\
\hline${ }^{57} \mathrm{Co}$ & $2.97+7$ & $8.10+6$ & $8.34+5$ & $2.76+5$ & $1.02-4$ & $1.06-4$ & 3.45 & -6 & $5.92-7$ & $2.12-4$ & $7.16+3$ \\
\hline${ }^{51} \mathrm{Cr}$ & $1.98+7$ & $5.55+6$ & $5.88+5$ & $1.99+5$ & $6.68-4$ & $7.12-4$ & 2.38 & -5 & $4.17-6$ & $1.41-3$ & $4.87+3$ \\
\hline${ }^{54} \mathrm{Mn}$ & $2.13+7$ & $5.91+6$ & $8.32+5$ & $2.84+5$ & $6.37-5$ & $6.72-5$ & 2.98 & -6 & $5.28-7$ & $1.34-4$ & $5.22+3$ \\
\hline${ }^{60} \mathrm{Co}$ & $9.65+6$ & $2.38+6$ & $1.79+5$ & $5.03+4$ & $4.69-6$ & $4.40-6$ & 1.04 & -7 & $1.52-8$ & $9.20-6$ & $2.21+3$ \\
\hline${ }^{99} \mathrm{Mo}$ & $5.41+5$ & $1.93+5$ & $2.75+4$ & $1.04+4$ & $1.84-4$ & $2.49-4$ & 1.12 & -5 & $2.20-6$ & $4.46-4$ & $1.53+2$ \\
\hline
\end{tabular}


For dose calculations, the ISOSHLD code ${ }^{(39)}$ was run in cylindrical geometry with cylindrical shielding for each of the pipe runs from the blanket module on. The blanket modules themselves were not considered, as they are highly activated structures in the first place. Dose calculations for the reference blanket are estimated in the previous work by Willenberg and Bickford. ${ }^{(4)}$ In this case, radionuclide inventories sputtered and deposited within the module as part of the transport process were calculated only to determine that fraction of the sputtering source terms remaining available for transport and deposition in the remainder of the coolant loop.

The pipe wall itself constitutes the only shielding used here. No additional shielding or thermal insulation around the pipe was considered as would be the case in actual plant use. Contact doses taken on the surface of the pipe then give a measure of the highest doses that could be expected during maintenance operations. The wall thicknesses assumed are given in Table 10.

To model the steam generator with ISOSHLD, the internal tube structure was homogenized over the internal space of the generator shell. The density of steel was reduced by the appropriate void fraction. Air was used for the void, helium not being available in the code library. The code was then run assuming a uniform distribution of one curie for each radionuclide of interest

\section{TABLE 10. Wal1 Thickness for Pipe Runs}

Component

Ring Header

Ring Header to Toroidal

Manifold

Toroidal Manifold

To Steam Generator

Steam Generator

Shell

Tubes

Circulator

Cold Return
Wall Thickness, cm

1.0

1.5

4.5

6.0

11.0

0.20

6.0

6.0 
in the generator and for each pipe run. Linear scaling with the predicted activities then gave the contact doses predicted for each component in the cooling system. 


\subsection{RESULTS}

The coolant and surface radionuclide concentrations predicted by the transport model are given in Tables 11 and 12 for the blanket module and remainder of the coolant loop, respectively. The average concentrations along each branch are given, as predicted by Equations 19 and 20. Using the averages

gives the appearance of discontinuities in coolant concentrations (atoms $/ \mathrm{cm}^{3}$ ) across branches such as between the Zone 3 and Zone 3 collection branches. The concentrations are in fact continuous across branch junctions.

In Table 12, the values given for the ring leader and toroidal manifold are also averages. Surface concentrations in the ring header actually increase around its circumference with the addition of each blanket module output. The same is true of the toroidal manifold which again picks up the output of 9 ring segments. Table 13 gives the average concentrations along segments of the toroidal manifold as ring segments are picked up. Only 4 segments are shown, considering symmetry around the output run to the steam generator. Note that the concentrations in the coolant remain constant as expected. However, surface concentrations drop significantiy from the "to toroidal manifold" run upon entering the much larger toroidal manifold. This is discussed below. Surface concentrations then gradually increase to roughly half the levels found in the "to toroidal manifold" run as the output from more ring segments is added.

In Table 14, the total inventories predicted in the components have been calculated as a computational check on the transport model mathematics. The total inventory in curies is given knowing the surface area, volume, and number of components as presented earlier. Comparing the resulting totals in Table 14 with the original source terms given in Table 9 indicates that the branch by branch transport method accounts for $297 \%$ of the original input. This is considered a reasonable accuracy given the number of branch steps involved.

Table 14 also shows that approximately $17 \%$ of all radionuclides released by sputtering in the blanket are predicted to deposit out in the modules themselves. About $8 \%$ deposit out on the various pipe runs, with the remaining $75 \%$ 
TABLE 11. Average Inventories in the Blanket Module

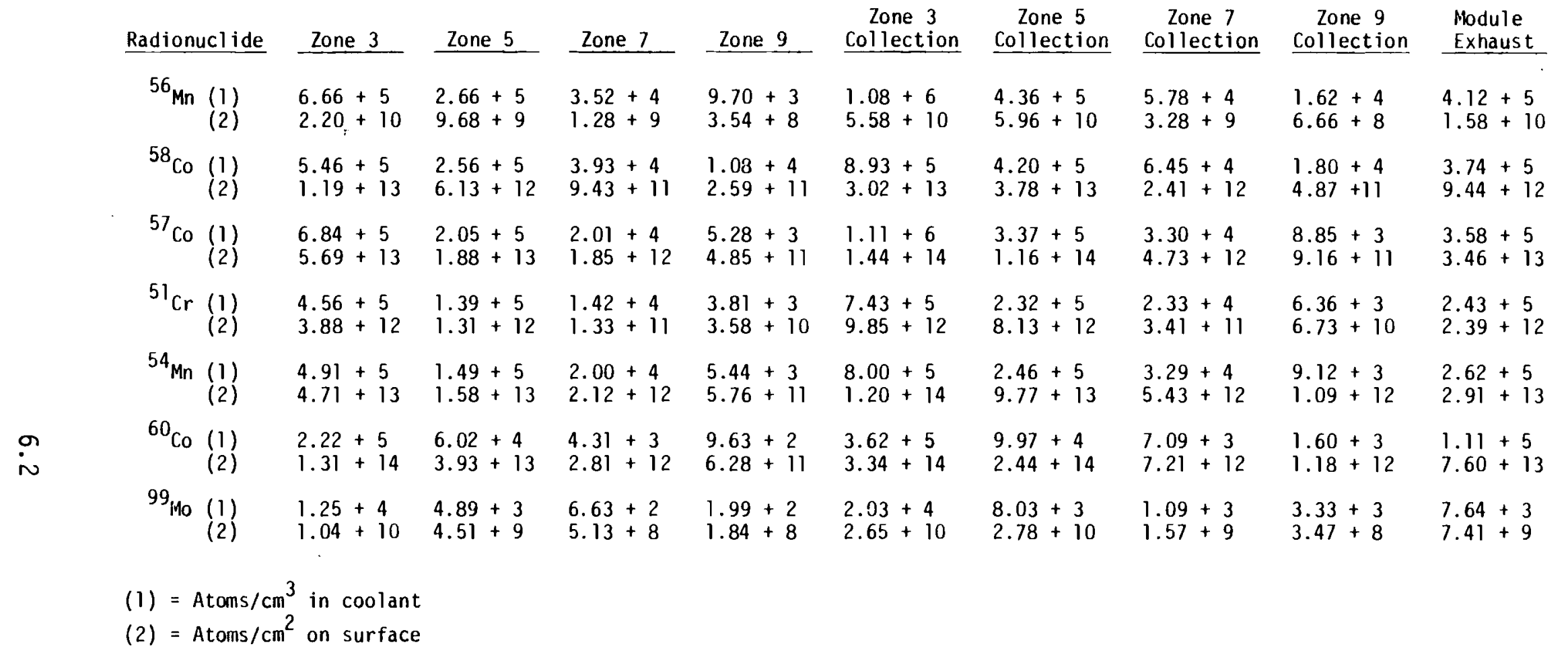


TABLE 12. Average Inventories in the Coolant Loop

\begin{tabular}{|c|c|c|c|c|c|c|c|}
\hline Radionuclide & $\begin{array}{l}\text { Ring } \\
\text { Header }\end{array}$ & $\begin{array}{l}\text { To Toroidal } \\
\text { Manifold } \\
\end{array}$ & $\begin{array}{l}\text { Toroidal } \\
\text { Manifold } \\
\end{array}$ & $\begin{array}{l}\text { To Steam } \\
\text { Generator }\end{array}$ & $\begin{array}{c}\text { Steam } \\
\text { Generator } \\
\end{array}$ & Circulator & $\begin{array}{l}\text { Cold } \\
\text { Return }\end{array}$ \\
\hline${ }^{56} \operatorname{Mn~(1)~}$ & $\begin{array}{l}4.25+5 \\
1.49+10\end{array}$ & $\begin{array}{l}4.19+5 \\
2.12+10\end{array}$ & $\begin{array}{l}4.09+5 \\
5.84+9\end{array}$ & $\begin{array}{l}3.98+5 \\
9.61+9\end{array}$ & $\begin{array}{l}8.48+4 \\
2.62+9\end{array}$ & $\begin{array}{l}4.03+3 \\
6.97+7\end{array}$ & $\begin{array}{l}3.87+3 \\
6.70+7\end{array}$ \\
\hline${ }^{58}$ Co (1) & $\begin{array}{l}3.85+5 \\
8.93+12\end{array}$ & $\begin{array}{l}3.81+5 \\
1.27+13\end{array}$ & $\begin{array}{l}3.71+5 \\
3.49+12\end{array}$ & $\begin{array}{l}3.61+5 \\
5.73+12\end{array}$ & $\begin{array}{l}7.67+4 \\
1.56+12\end{array}$ & $\begin{array}{l}3.65+3 \\
4.16+10\end{array}$ & $\begin{array}{l}3.50+3 \\
3.99+10\end{array}$ \\
\hline${ }^{51} \mathrm{Cr}$ (1) & $\begin{array}{l}2.49+5 \\
2.26+12\end{array}$ & $\begin{array}{l}2.47+5 \\
3.21+12\end{array}$ & $\begin{array}{l}2.41+5 \\
8.83+11\end{array}$ & $\begin{array}{l}2.33+5 \\
1.45+12\end{array}$ & $\begin{array}{l}4.96+4 \\
3.95+11\end{array}$ & $\begin{array}{l}2.35+3 \\
1.05+10\end{array}$ & $\begin{array}{l}2.26+3 \\
1.01+10\end{array}$ \\
\hline${ }^{54} \mathrm{Mn}(1)$ & $\begin{array}{l}2.69+5 \\
2.75+13\end{array}$ & $\begin{array}{l}2.66+5 \\
3.91+13\end{array}$ & $\begin{array}{l}2.61+5 \\
1.08+13\end{array}$ & $\begin{array}{l}2.54+5 \\
1.78+13\end{array}$ & $\begin{array}{l}5.41+4 \\
4.87+12\end{array}$ & $\begin{array}{l}2.58+3 \\
1.30+11\end{array}$ & $\begin{array}{l}2.48+3 \\
1.25+11\end{array}$ \\
\hline $\begin{array}{l}(1)=\text { Atoms } \\
(2)=\text { Atoms }\end{array}$ & $\begin{array}{l}\text { in coola } \\
\text { on surfa }\end{array}$ & & & & & & \\
\hline
\end{tabular}


TABLE 13. Surface Buildup in the Toroidal Manifold

Radionucl ide

\begin{tabular}{|c|c|c|c|}
\hline$T$ & 2 & 3 & 4 \\
\hline $\begin{array}{l}4.11+5 \\
2.87+9\end{array}$ & $\begin{array}{l}4.09+5 \\
4.98+9\end{array}$ & $\begin{array}{l}4.08+5 \\
6.87+9\end{array}$ & $\begin{array}{l}4.07+5 \\
8.62+9\end{array}$ \\
\hline $\begin{array}{l}3.73+5 \\
1.72+12\end{array}$ & $\begin{array}{l}3.71+5 \\
2.97+12\end{array}$ & $\begin{array}{l}3.70+5 \\
4.11+12\end{array}$ & $\begin{array}{l}3.70+5 \\
5.15+12\end{array}$ \\
\hline $\begin{array}{l}3.56+5 \\
6.27+12\end{array}$ & $\begin{array}{l}3.54+5 \\
1.09+13\end{array}$ & $\begin{array}{l}3.54+5 \\
1.50+13\end{array}$ & $\begin{array}{l}3.53+5 \\
1.88+13\end{array}$ \\
\hline $\begin{array}{l}2.42+5 \\
4.35+11\end{array}$ & $\begin{array}{l}2.41+5 \\
7.55+11\end{array}$ & $\begin{array}{l}2.40+5 \\
1.04+12\end{array}$ & $\begin{array}{l}2.39+5 \\
1.30+12\end{array}$ \\
\hline $\begin{array}{l}2.62+5 \\
5.31+12\end{array}$ & $\begin{array}{l}2.61+5 \\
9.22+12\end{array}$ & $\begin{array}{l}2.61+5 \\
1.28+13\end{array}$ & $\begin{array}{l}2.60+5 \\
1.60+13\end{array}$ \\
\hline $\begin{array}{l}1.11+5 \\
1.39+13\end{array}$ & $\begin{array}{l}1.11+5 \\
2.43+13\end{array}$ & $\begin{array}{l}1.12+5 \\
3.36+13\end{array}$ & $\begin{array}{l}1.11+5 \\
4.19+13\end{array}$ \\
\hline $\begin{array}{l}7.63+3 \\
1.35+9\end{array}$ & $\begin{array}{l}7.60+3 \\
2.34+9\end{array}$ & $\begin{array}{l}7.58+3 \\
3.23+9\end{array}$ & $\begin{array}{l}7.55+3 \\
4.05+9\end{array}$ \\
\hline
\end{tabular}

(1) $=$ Atoms $/ \mathrm{cm}^{3}$ in coolant

(2) $=$ Atoms $/ \mathrm{cm}^{2}$ on surface

depositing out in the steam generator. As expected, the deposition pattern in the loop is highly dependent on the helium flow velocity, and especially the pipe diameters used. Going back to Equation 16, the decrease in concentrations along a pipe run of length $x$ is given by $e^{-a x}$. For relatively long lived radionuclides and circular coolant channels, the factor "a" as given in Equation 16 reduces to

$$
\mathrm{a} \simeq \frac{4 h}{\mathrm{vd}} \text {. }
$$

where the mass transfer coefficient $h$ is as given in Equation 17. Reducing Equation 21 in terms of velocity and dicmeter gives

$$
a \propto v^{-0.2} d^{-1.2} \text {. }
$$


TABLE 14. Activity in the Coolant Loop

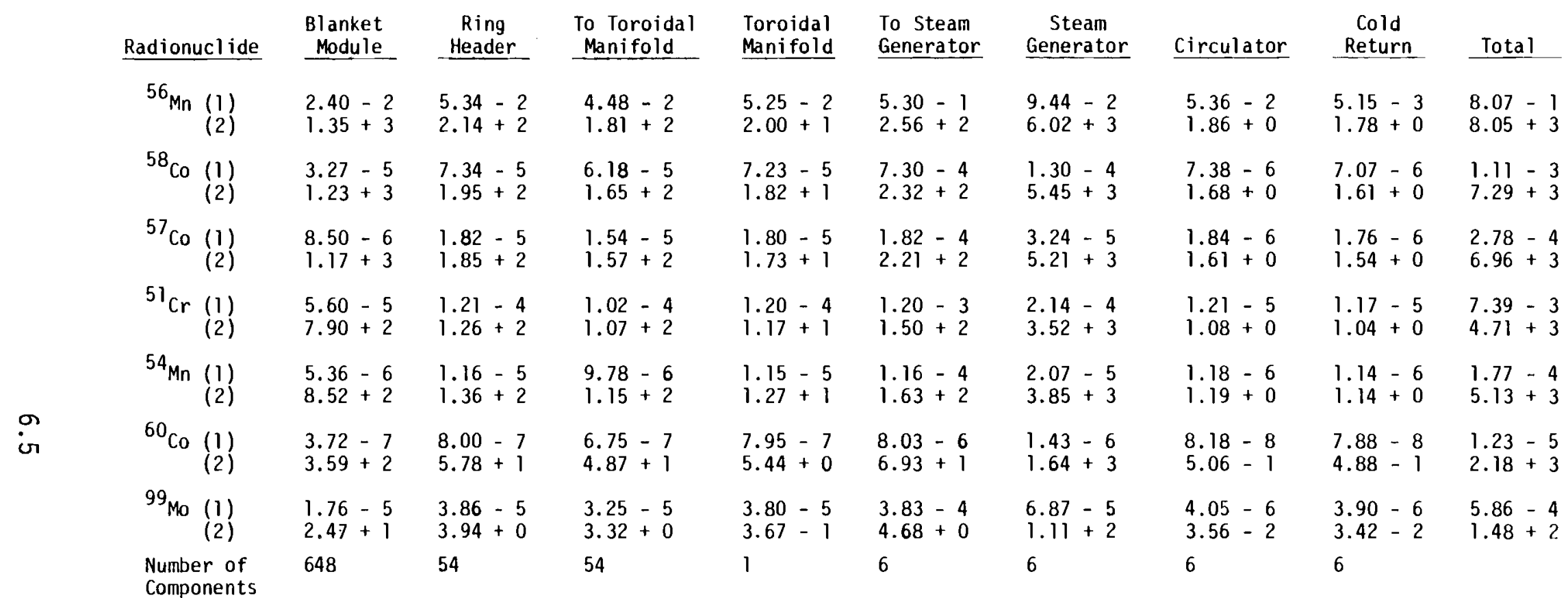

(1) $=C i$ in coolant

(2) $=\mathrm{Ci}$ on surface 
Deposition along the channel is then exponential, increasing with decreasing velocity and decreasing diameter. Decreasing the first wall tube diameters to $1 \mathrm{~cm}$, deposition along runs of $50 \mathrm{~cm}$ could reduce inventories by up to $30 \%$ while maintaining reasonable velocities and heat transfer values $(\mathrm{v}=17 \mathrm{~m} / \mathrm{sec}$, $\mathrm{H}=0.12$ watts $\left./ \mathrm{cm}^{2} \cdot{ }^{\circ} \mathrm{C}\right)$.

The activation product inventories have dropped off substantially after passage through the steam generator. The circulator and cold return are given in Table 14. The portions of the cold leg not given (toroidal manifold, blanket delivery, ring headers, etc.) will have activation products present, however, the inventories are not significant. The activity levels returned in the cold helium leg to the blanket modules are such that it is essentially a "clean" helium supply as was initially assumed. No iterative process is necessary to converge on the equilibrium coolant concentrations.

Finally, Table 15 gives the predicted contact dose rates for the various components in the coolant loop. The highest dose rate predicted outside the blanket is on the pipe runs to the toroidal manifold at $\sim 1 \times 10^{4} \mathrm{mR} / \mathrm{hr}$. For the toroidal manifold, the average dose expected is $7.6 \times 10^{2} \mathrm{mR} / \mathrm{hr}$. This would increase by a factor of 21.5 at the point of maximum surface inventory. The reduction in predicted dose rates on the toroidal manifold and run to the steam generator is significant, primarily due to the assumed pipe wall thicknesses.

Contact doses predicted for the steam generator are $2100 \mathrm{mR} / \mathrm{hr}$. Al though the generators contain $75 \%$ of the radionuclide inventory, the large surface areas and thick shell wall effectively reduce the hazard. However, the dose rates are still significant from a maintenance viewpoint.

On the circulator and cold return, the predicted contact dose rates become negligible. Dose rates in the remainder of the cold leg would be similar.

In genera1, the contact doses predicted are comparable to those currently experienced in the light water reactor industry.

For loss of coolant or blow-down type accidents, the activation product inventories entrained in the coolant are of interest. Taken from Table 14, 
TABLE 15. Contact Dose Rates

\begin{tabular}{|c|c|c|c|c|c|c|c|}
\hline Radionuclide & $\begin{array}{c}\text { Ring } \\
\text { Header } \\
\text { (Average) } \\
\end{array}$ & $\begin{array}{l}\text { To Toroidal } \\
\text { Manifold } \\
\end{array}$ & $\begin{array}{l}\text { Toroidal } \\
\text { Manifold } \\
\text { (Average) }\end{array}$ & $\begin{array}{l}\text { To Steam } \\
\text { Generator }\end{array}$ & $\begin{array}{c}\text { Steam } \\
\text { Generator }\end{array}$ & Circulator & $\begin{array}{c}\text { Cold } \\
\text { Return } \\
\end{array}$ \\
\hline${ }^{56} 6_{\mathrm{Mn}}$ & $4.05+3$ & $4.67+3$ & $3.80+2$ & $3.53+2$ & $6.76+1$ & $2.56+0$ & $2.45+0$ \\
\hline${ }^{58} \mathrm{Co}_{0}$ & $2.17+3$ & $2.39+3$ & $1.43+2$ & $1.13+2$ & $8.45+0$ & $8.17-1$ & $7.83-1$ \\
\hline${ }^{57} \mathrm{Co}$ & $3.96+1$ & $1.92+1$ & $8.60-3$ & $6.12-4$ & $1.75-8$ & $4.46-6$ & $4.27-6$ \\
\hline${ }^{51} \mathrm{Cr}$ & $3.78+1$ & $3.67+1$ & $1.07+0$ & $5.83-1$ & $9.27-3$ & $4.20-3$ & $4.04-3$ \\
\hline${ }^{54} \mathrm{Mn}$ & $1.29+3$ & $1.44+3$ & $9.01+1$ & $7.24+1$ & $5.50+0$ & $5.29-1$ & $5.06-1$ \\
\hline${ }^{60} \mathrm{Co}$ & $1.56+3$ & $1.80+3$ & $1.46+2$ & $1.31+2$ & $1.83+1$ & $9.58-1$ & $9.09-1$ \\
\hline${ }^{99}{ }_{\mathrm{Mo}}$ & $1.27+0$ & $9.65-1$ & $1.16-2$ & $4.22-3$ & $1.72-5$ & $3.21-5$ & $3.09-5$ \\
\hline $\begin{array}{l}\text { Total } \\
\text { Dose, } \\
\mathrm{mR} / \mathrm{hr}\end{array}$ & $9.15+3$ & $1.04+4$ & $7.60+2$ & $6.70+2$ & $9.99+1$ & $4.87+0$ & $4.65+0$ \\
\hline
\end{tabular}


the predicted inventories are again shown in Table 16 along with the maximum permissable concentrations allowed for occupational exposure. The dilution required to meet these MPCs is also given. The volume of air given is only for relative comparison between nuclides. Because of the extremely low vapor pressures of the activation products, deposition on any and all surfaces is highly probable during and immediately following the release. Airborne concentrations would then decrease rapidly by a mechanism other than simple dispersion and dilution, and the given quantities of air would almost assuredly not be required. However, the dilution that may be necessary is not insignificant, particularly for ${ }^{56} \mathrm{Mn}$.

The inventory of activation products deposited out in the hot leg of the coolant system is not though to present an additional hazard during blow-down

TABLE 16. Entrained Coolant Inventories

\begin{tabular}{|c|c|c|c|}
\hline Radionuclide & $\begin{array}{l}\text { Inventory } \\
\text { (Ci) }\end{array}$ & $\begin{array}{l}\text { Occupational } \\
\mathrm{MPC}\left(\mathrm{Ci} / \mathrm{m}^{3}\right) \\
\end{array}$ & $\begin{array}{l}\text { Dilution } \\
\text { (m } \mathrm{m}^{3} \text { of Air) } \\
\end{array}$ \\
\hline${ }^{56} \mathrm{Mn}$ & $8.07-1$ & $\begin{array}{l}\text { S } 8.0-7 \\
\text { I } 5.0-7\end{array}$ & $\begin{array}{l}1.0+6 \\
1.6+6\end{array}$ \\
\hline${ }^{58} \mathrm{Co}$ & $1.11-3$ & $\begin{array}{l}S 2.0-5 \\
\text { I } 9.0-6\end{array}$ & $\begin{array}{l}5.6+1 \\
1.2+2\end{array}$ \\
\hline${ }^{57} \mathrm{Co}$ & $2.78-4$ & 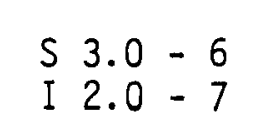 & $\begin{array}{l}9.3+1 \\
1.4+3\end{array}$ \\
\hline${ }^{51} \mathrm{Cr}$ & $7.39-3$ & $\begin{array}{l}\text { S } 1.0-5 \\
\text { I } 2.0-6\end{array}$ & $\begin{array}{l}7.4+2 \\
3.7+3\end{array}$ \\
\hline${ }^{54} \mathrm{Mn}$ & $1.77-4$ & $\begin{array}{l}\text { S } 4.0-7 \\
\text { I } 4.0-8\end{array}$ & $\begin{array}{l}4.4+2 \\
4.4+3\end{array}$ \\
\hline${ }^{60} \mathrm{Co}$ & $1.23-5$ & $\begin{array}{l}\text { S } 3.0-7 \\
\text { I } 9.0-9-9\end{array}$ & $\begin{array}{l}4.1+1 \\
1.4+3\end{array}$ \\
\hline${ }^{99}$ Mo & $5.86-4$ & $\begin{array}{l}\text { S } 7.0-7 \\
\text { I } 2.0-7\end{array}$ & $\begin{array}{l}8.4+2 \\
2.9+3\end{array}$ \\
\hline \multicolumn{4}{|l|}{$S=$ Soluble } \\
\hline$I=$ Insoluble & & & \\
\hline
\end{tabular}


accidents. The sticking probabilities and adhesion of sputtered material on the coolant channel walls is expected to be excellent, reducing the likelihood of resuspension. However, it may be advantageous to investigate 1 ift-off type phenomenon as part of the safety program. 
. 


\subsection{CONCLUSIONS}

The transport and deposition of activation products in a compact helium cooled tokamak fusion power plant have been investigated. The parameters of a reference reactor and cooling loop using stainless steel type 316 were established, and release terms for activation products into the coolant stream were identified. Corrosion was assumed to be negligible at the reference operating conditions. Neutron sputtering was the major source. This included the bulk removal of material by lattice dynamic neutron sputtering and the direct ejection of daughter radionuclides produced in $(n, x)$ type reactions. The inventory released was in excess of $3 \times 10^{4}$ curies in equilibrium.

Modeling techniques developed to predict fission product transport in gas cooled reactors were used here. These models have proved successful in predicting transport and deposition of radionuclides in gas cooled systems, particularly for fission products with low vapor pressures such as $2 r-95$ and $\mathrm{Ru}-103$. Walls can be treated as perfect sinks, where vapor pressure is assumed to be zero over the surface. This assumption is applicable to the fusion environment, where the activation products released ( $\mathrm{Mn}, \mathrm{Co}, \mathrm{Cr}$, etc.) have extremely low vapor pressures under normal operating conditions. The transport mechanism is then solely one of convection along the flow path until deposition on the channel wall occurs.

As expected from the transport model mathematics, the deposition of sputtered activation products in the coolant loop proved to be dependent on helium flow velocity, and highly dependent on the channel diameter. Low velocities and small diameters promote deposition. With the reference parameters assumed, about 17\% of the inventory deposited out in the blanket modules themselves. Onty $8 \%$ deposited in the larger pipe runs in the hot leg, with the remaining $75 \%$ depositing in the steam generators. Deposition in the circulator and cold return leg was negligible.

Contact dose rates were predicted for bare steel pipe runs in the coolant system. On hot pipes coming from the blanket $(d=50 \mathrm{~cm})$, doses were as high as $1 \times 10^{4} \mathrm{mR} / \mathrm{hr}$. Helium flow was then collected in a main toroidal helium 
header of $150 \mathrm{~cm}$ minor diameter, where contact doses were predicted as high as $21 \times 10^{3} \mathrm{mR} / \mathrm{hr}$. Although $75 \%$ of the inventory resided in the steam generators, contact doses were predicted at $100 \mathrm{mR} / \mathrm{hr}$ due to the assumed shell thickness $(11 \mathrm{~cm})$ and self shielding. Contact doses on the cold leg of the cooling system were negligible, being under $5 \mathrm{mR} / \mathrm{hr}$.

With the exception of ${ }^{56} \mathrm{Mn}$, radionuclide inventories entrained in the coolant were such that $210^{4} \mathrm{~m}^{3}$ of air would be required to dilute the entire inventory to maximum permissible concentrations in the case of a blow-down type accident. This is considered to be an over-estimate of the required dilution due to deposition during and immediately following the release. The activation products of interest ( $\mathrm{Mn}, \mathrm{Co}, \mathrm{Cr}$, etc.) have extremely low vapor pressures, and all surfaces encountered will act as pumps to rapidly lower airborne inventories.

For ${ }^{56} \mathrm{Mn}$, the predicted entrained inventory was $0.8 \mathrm{Ci}$. As such, significant dilution would be required to reach MPCs ( $210^{6} \mathrm{~m}^{3}$ of air). It is unknown at present how rapid deposition in the reactor hall would be, or if this indicates the need for filtering or spray systems in the building.

In conclusion, contact dose rates and radionuclide inventories entrained in the coolant have been found to present a significant occupational safety hazard in this preliminary look at transport and deposition in a helium cooled fusion power plant. Predicted doses were comparable to those found in the LWR industry. However, the deposition patterns were highly dependent on coolant channel diameter and coolant velocity. It appears that deposition in the first wall and blanket region could be significantly increased from $17 \%$ of the available inventories while maintaining adequate cooling performance.

The ability to enhance deposition of activation products in the first wall and blanket region of a gas cooled fusion reactor adds another dimension to cooling system design. The blanket region is, of course, exposed directly to the fusion neutron flux producing highly activated structures, and is the source of sputtered activation products. Permanent deposition here presents no additional radiation hazard outside the reactor shielding and hence is desirable from an occupational safety viewpoint. It appears that with the 
reduction of coolant channel diameters to $\sim 1 \mathrm{~cm}$, deposition will approach $30 \%$ of available inventories along runs of $50 \mathrm{~cm}$. It remains to be seen if adequate thermal hydraulic characteristics and heat removal can be maintained. A reduction in coolant velocity can also enhance deposition, but if used it would likely have to be augmented with the use of surface roughness techniques as advocated by General Atomic to maintain adequate surface heat transfer coefficients. It remains to find the maximum reduction in activation product inventories available for transport from the blanket while still meeting the criteria for heat removal. 


\section{REFERENCES}

1. B. J. Verna, "Occupational Exposure," Nuclear News, July 1977. pp. 38-40 and September, pp. 42-43.

2. D. L. Hanson, N. L. Baldwin and W. E. Selph, Gamma Scanning the Primary Circuit of the Peach Bottom HTGR. GA-A14161, General Atomic, San Diego, CA, 1976.

3. W. F. Brehm, "Radioactive Corrosion Product Transport and Control." Proceedings of the American Nuclear Society International Conference on Liquid Metal Technology in Energy Production, Champion, PA, 1976. CONF-760503-P7.

4. H. J. Willenberg, W. E. Bickford, Safety Aspects of Activation Products in a Compact Tokamak Fusion Power Plant. PNL-2823, Pacific Northwest Laboratory, Richland, WA 99352, October 1978.

5. D. Steiner, et a1., ORNL Fusion Power Demonstration Study: Interim Report. ORNL/TM-5813, Oak Ridge Nationa1 Laboratory, Oak Ridge, TN 37830, March 1977.

6. F. E. Vanslanger, L. D. Mears. PAD, A Computer Code for Calculating the Plateout Activity Distribution in a Reactor Circuit. GA-10460, General Atomic, San Diego, CA, 1971.

7. W. W. Hudritsch and P. D. Smith, PADLOC, A One-Dimensional Computer Code for Calculating Coolant and Plateout Fission Product Concentrations. GA-A14407, Genera1 Atomic, San Diego, CA, November 1977.

8. B. Badger, et a1., UWMAK-II, A Conceptual Tokamak Reactor Design. UWFDM-112, University of Wisconsin, Madison, WI 53706, October 1975, pp. VI-B-4.

9. T. J. Kabele, et al., Activated Corrosion Product Radiation Levels Near FFTF Reactor and Closed Loop Primary System Components. HEDL-TME 72-7T, Hanford Engineering DeveTopment Laboratory, Richland, WA 99352, May 1972.

10. W. L. Kuhn, Activated Corrosion Product Radiation Levels in the FFTF Heat Transport System Cells and Closed Loop Sys tem Modules. HEDL-TME 76-10, Hanford Engineering Development Laboratory, Richland, WA 99352, September 1977.

11. D. L. Hanxon, N. L. Baldwin, W. E. Selph, op. cit., p. 3.

12. R. W. Werner, ORNL Fusion Power Demonstration Study: The Concept of the Cassette Blanket. ORNL/TM-5964, Oak Ridge National Laboratory, Oak Ridge, TN 37830, October 1977. 
13. B. Badger, et a1., op. cit., pp. IV-D-11.

14. C. C. Baker, et a1., Conceptual Design Study of a Noncircular Tokamak Demonstration Fusion Power Reactor. GA-A13992, General Atomic, San Diego, CA, November 1976.

15. R. W. Werner, op. cit., pp. 12.

16. D. L. Hanson, N. L. Baldwin, and W. E. Selph, op. cit., pp. 37.

17. C. W. Stewart, et al., The Limits of Helium Cooling in Fusion Reactor First Walls and Blankets. PNL-2477, Pacific Northwest Laboratory, Richland, WA 99352, January 1978.

18. C. C. Baker, et al., op. cit., pp. 4-69.

19. W. E. Bickford, Coolant Channel Sputtering Source Terms in a Compact Tokamak Fusion Power Plant. PNL-2942, Pacific Northwest Laboratory, Richland, WA 99352, March 1979, pp.13.

20. B. Badger, et al., op. cit., pp. IV-C-12.

21. W. W. Engle, A User's Manual for ANISN. K-1693, Oak Ridge Gaseous Diffusion Plant, Oak Ridge, Ti, 1967.

22. R. T. Perry, et al., INDRA: A Program System for Calculating the Neutronics and Photonics Characteristics of a Fusion Reactor BTanket. IPP4/137, Max-Planck-Institut für Plasmaphysik, Garching, West Germany, 1976.

23. P. Sigmund, "Theory of Sputtering." Physical Review. 184 (2):383, 1969.

24. D. L. Lessor, M. T. Thomas and 0. K. Harling, "Projected Range Calculations of Radionuclide Product Ejection from Metal Surfaces by $14.8 \mathrm{MeV}$ Neutrons." Journal of Applied Physics. 48 (10):4337, 1977.

25. W. E. Bickford, op. cit., pp. 17.

26. M. T. Thomas, 0. K. Harling, R. L. Brodzinski, and L. A. Rancitelli, "Fusion Neutron Induced Radioactive Emissions from Surfaces." Journal of Nuclear Materials. 63, pp. 452, 1976.

27. T. Tanabe and S. Imoto, "Surface Analys is of SUS 316 by SIMS, SEM and ESCA." Journal of Nuclear Materials. 80:pp. 361, 1979.

28. T. Tanabe and S. Imoto, "Surface Oxidation of Type 316 Stainless Steel." Transactions of the Japan Institute of Metals. 20:pp.507, 1979.

29. F. N. Mazandarany, Effects of Elevated Temperature Exposure to a Simulated HTGR Primary Coolant Environment on Several Unstressed Austenitic Alloys. GA-A-13462, General Atomic, San Diego, CA, August 1975, pp. 23. 
30. S. N. Rosenwasser and W. R. Johnson, Gas Turbine HTGR Materials Screening Test Program. GA-A-14122, General Atomic, San Diego, CA, September 1976.

31. R. E. Westerman and L. A. Charlot, Review of Metals Applications in HTGRs. BNWL-B-246, Pacific Northwest Laboratory, Richland, WA 99352, February 1973.

32. C. E. Apperson, Jr., SUVIUS: A Circulating and Plateout Activity Program for Gas-Cooled Reactors with Arbitrary Radioactive Chains. LA-7239-MS, Los Alamos Scientific Laboratory, Los Alamos, NM 87545, May 1978.

33. M. J. Lawler, Deposition of Fission Products in a Primary Heat Exchanger of the Dragon HTR. SRD-R-35, Uni ted Kingdom Atomic Energy Authority. Wigshaw Lane, Culcheth WA 3 4NE, Warrington, 1974.

34. J. M. Dickey, A Model for the Migration of the Fission Products Along the Coolant Channels of a High Temperature Gas Cooled Reactor Following a Hypothetical Accident of Complete Loss of Cooling. BNL-NUREG-24410, Brookhaven Nationa 1 Laboratory, Upton, NY 11973, May 1978.

35. D. L. Hanson, Results of the General Atomic Deposition Loop Program. GA-A13140, General Atomic, San Diego, CA, April 1976.

36. G. E. Raines, et al., Experimental and Theoretical Studies of FissionProduct Deposition in Flowing Helium. BMI-1688, Battelle Memoria? Institute, Columbus, OH, August 1964.

37. D. L. Hanson, A Review of Fission Product Plateout Investigations at General Atomic. GA-A14555, General Atomic, San Diego, CA, December 1977.

38. D. L. Hanson, op. cit., GA-A13140, pp. 8.

39. R. L. Enge 1, J. Greenborg and M. M. Hendrickson, ISOSHLD - A Computer Code for General Purpose Iostope Shielding Ana Tys is. BNWL-236, Pacific Northwest Laboratory, Richland, WA 99352, June 1966.

40. W. E. Willingham, L. B. Ufkes, W. S. Graves, The VITRO Engineering ISOSHLD User's Manual. VITR0-R-153, Automation Industries, Inc., P.0. Box 296, Richland, WA 99352, March 1972.

41. C. A. Mansius, A Revised Photon Probability Library for Use with ISOSHLD-III. BNWL-236, Supplement 2, Battelle, Pacific Northwest Laboratory, RichTand, WA 99352, Apri1. 1969. 



\section{DISTRIBUTION}

OFFSITE

No. of

Copies

A. A. Churm

DOE Patent Division

9800 South Cass Avenue

Argonne, IL 60439

27 DOE Technical Information Center

J. E. Baublitz

DOE Office of Fusion Energy - ETM Washington, DC 20545

N. A. Amherd

Electric Power Research Institute $3412 \mathrm{Hillview} \mathrm{Avenue}$

Palo Alto, CA 94304

H. J. Brockmann

Kernforschungsanlage Jülich $\mathrm{GmbH}$

Postfach 1913

05170 Jülich

West Germany

I. Charak

Argonne National Laboratory

97000 South Cass Avenue

Argonne, IL 60659

R. Cherdack

Burns \& Roe, Inc.

633 Industrial Avenue

Paramus, NJ 07652

R. W. Conn

University of Wisconsin

Madison, WI 53706

15 J. G. Crocker

$E G \& G$, Inc.

P.0. Box 1625

Idaho Falls, ID 83401
No. of

Copies

D. J. Dudziak

Los Alamos Scientific Laboratory

P.0. Box 1663

Los Alamos, NM 87545

C. E. Easterly

Oak Ridge National Laboratory

P.0. Box $X$

Oak Ridge, TN 37830

J. Gruber

Hahn-Meitner Institut für Kernforschung GmbH, C3

Glienicker Str. 100

D-1000 Berl in 39

West Germany

H. J. Howe, Jr.

Princeton Plasma Physics Laboratory

P.0. Box 451

Princeton, NJ 08540

T. J. Kabele

The Analytical Sciences Corporation

6 Jacob Way

Reading, MA 01867

K. E. Lind

Ebasco Services, Inc.

2 Reactor Street

New York, NY 10006

W. E. Kastenberg

Dept. of Chemical, Thermal and Nuclear Engineering

University of California

Los Angeles, CA 90254 
No. of

Copies

M. Kazimi

Dept. of Nuclear Engineering

Massachusetts Institute of Technology

Cambridge, MA 02139

V. A. Maroni

Argonne National Laboratory

Argonne, IL 60439

J. R. Powell

Brookhaven National Laboratory

Upton, NY 11973

R. T. Santoro

Oak Ridge National Laboratory P.0. Box $X$

Oak Ridge, TN 37830

P.E. Theiss

Nuclear Engineering Program

Dept. of Mechanical Engineering

The Catholic University of America

Washington, DC 20064

W. F. Voge lsang

Dept. of Nuclear Engineering

University of Wiscons in

Madison, WI 53706

H. J. Willenberg

Mathematical Sciences

Northwest, Inc.

P.0. Box 1887

Bellevue, WA 98009

G. L. Woodruff

Dept. of Nuclear Engineering

University of Washington

Seattle, WA 98195
No. of

Copies

ONSITE

DOE Richland Operations Office

W. A. Burns

H. E. Ransom

32 Pacific Northwest Laboratory

W. E. Bickford (15)

S. H. Bush

D. A. Dingee

B. F. Gore

B. R. Leonard, Jr.

D. L. Lessor

L. G. Morgan

M. T. Thomas

C. E. Willingham

Technical Information (5)

Publishing Coordination Ma (2)

Hanford Engineering Development Laboratory

L. D. Muhlestein 